\title{
Activation of the Aromatic Core of 3,3'-(Pyridine-2,6- diylbis(1H-1,2,3-triazole-4,1-diyl))bis(propan-1-ol)-Effects on Extraction Performance, Stability Constants, and Basicity
}

\author{
Patrik Weßling, ${ }^{*},+\ddagger \odot$ Michael Trumm, ${ }^{\dagger}$ Elena Macerata, ${ }^{*}, \S$ Annalisa Ossola, ${ }^{\S}$ Eros Mossini, ${ }^{\S}$
}

Maria Chiara Gullo," Arturo Arduini, ${ }^{\prime}$ Alessandro Casnati, ${ }^{*}, \|$ Mario Mariani, ${ }^{\S}$ Christian Adam, ${ }^{\dagger}$ (1) Andreas Geist, ${ }^{\dagger}$ and Petra J. Panak ${ }^{\dagger, \dagger}$

${ }^{\dagger}$ Institute for Nuclear Waste Disposal, Karlsruhe Institute of Technology, P.O. Box 3640, 76021 Karlsruhe, Germany

${ }^{\ddagger}$ Institut für Physikalische Chemie, Ruprecht-Karls-Universität Heidelberg, Im Neuenheimer Feld 253, 69120 Heidelberg, Germany

${ }^{\S}$ Politecnico di Milano, Department of Energy, Nuclear Engineering Division, Piazza Leonardo da Vinci 32, 20133 Milano, Italy

"Dipartimento di Scienze Chimiche, della Vita e della Sostenibilitá Ambientale, Universitá di Parma, Area delle Scienze 17/a, 43124

Parma, Italy

Supporting Information

ABSTRACT: The "CHON" compatible water-soluble ligand 3,3' -(pyridine-2,6-diylbis ( $1 H$-1,2,3-triazole-4,1-diyl)) bis(propan-1-ol) (PTD) has shown promise for selectively stripping actinide ions from an organic phase containing both actinide and lanthanide ions, by preferential complexation of the former. Aiming at improving its complexation properties, PTD-OMe was synthesized, bearing a methoxy group on the central pyridine ring, thus increasing its basicity and hence complexation strength. Unfortunately, solvent extraction experiments in the range of $0.1-1 \mathrm{~mol} / \mathrm{L}$ nitric acid proved PTD-OMe to be less efficient than PTD. This behavior is explained by its greater $\mathrm{p} K_{\mathrm{a}}$ value $\left(\mathrm{p} K_{\mathrm{a}}=2.54\right)$ compared to PTD $\left(\mathrm{p} K_{\mathrm{a}}=2.1\right)$. This counteracts its improved complexation properties for $\mathrm{Cm}(\mathrm{III})\left(\log \beta_{3}(\mathrm{PTD}-\mathrm{OMe})=10.8 \pm 0.4\right.$ versus $\left.\log \beta_{3}(\mathrm{PTD})=9.9 \pm 0.5\right)$.

\section{INTRODUCTION}

Hydrophilic N-donor complexing agents are used in several solvent extraction processes developed to separate actinides from lanthanides. ${ }^{1-3}$ Such separations may play a role in future advanced nuclear fuel cycles. On the basis of the chemistry of the TALSPEAK process, ${ }^{4,5}$ actinide and lanthanide ions are coextracted, followed by selective stripping of actinides using $\mathrm{N}$ donor complexing agents such as aminopolycarboxylates or sulfonated N-heterocyclic compounds. ${ }^{6-13}$

For this purpose, 3,3'-(pyridine-2,6-diylbis $(1 H$-1,2,3-triazole-4,1-diyl))bis(propan-1-ol) (PTD, Scheme 1$)^{14}$ is currently studied in the European research program GENIORS. ${ }^{15}$

Scheme 1. Molecular Structure of PTD and PTD-OMe

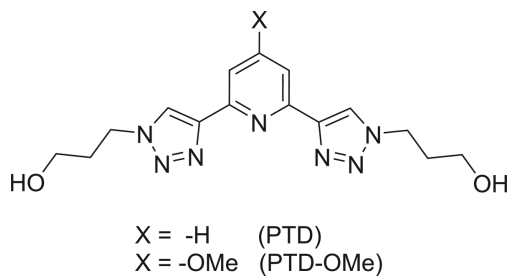

In contrast to aminopolycarboxylates, PTD remains efficient in up to $0.5 \mathrm{~mol} / \mathrm{L}$ nitric acid, which is advantageous with respect to process applications. Furthermore, PTD (other than sulfonated N-heterocyclic compounds) is a "CHON" compound (i.e., containing only carbon, hydrogen, oxygen, and nitrogen, making it fully combustible to gaseous products without generating solid wastes). ${ }^{16}$ The favorable properties of PTD such as pronounced selectivity for actinides(III) over lanthanides(III), fast kinetics, and good stability ${ }^{14,17}$ make it a promising candidate for process development. ${ }^{18}$

To further improve its complexation properties, a modified PTD was synthesized, PTD-OMe (Scheme 1). Adding a methoxy group in the para position of the pyridine ring to activate the aromatic core, metal ion complexation should be improved due to the higher electron density in the aromatic ring. Such modifications had successfully been employed to tune the properties of lipophilic of 2,6-bis-triazinyl-pyridine $(\mathrm{BTP})^{19}$ and 2,9-bis-triazinyl-1,10-phenanthroline (BTPhen) $)^{20,21}$ compounds.

Received: August 1, 2019

Published: October 14, 2019 
Scheme 2. Synthesis of PTD-OMe

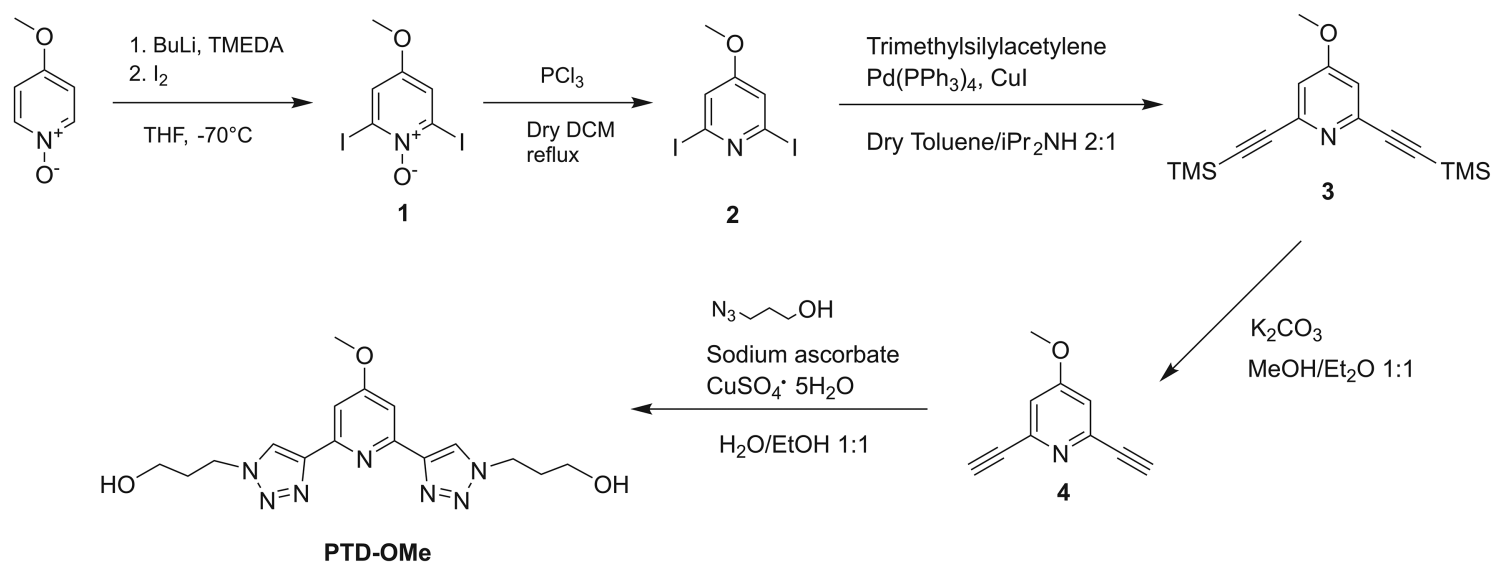

PTD-OMe was studied using solvent extraction, timeresolved laser fluorescence spectroscopy (TRLFS), and NMR. The $\mathrm{p} K_{\mathrm{a}}$ value, stability constants for the complexation of $\mathrm{Cm}$ (III), and the $\mathrm{Cm}$ (III) speciation in solution were determined. Computational calculations based on density functional theory (DFT) of actinide and lanthanide PTDOMe complexes were performed to support experimental findings.

\section{EXPERIMENTAL SECTION}

Chemicals. PTD-OMe was synthesized as described below (Scheme 2). $\mathrm{D}_{2} \mathrm{O}$ was purchased from Deutero $\mathrm{GmbH}$. All commercially available chemicals (Sigma-Aldrich) used in this study were analytical reagent grade and used without further purification.

Synthesis. Melting points were determined on an Electrothermal apparatus in capillaries sealed under nitrogen. ${ }^{1} \mathrm{H}$ and ${ }^{13} \mathrm{C}$ NMR spectra were recorded on Bruker AV300 and AV400 spectrometers. J coupling constants are given in hertz. Partially deuterated solvents were used as internal standards. Electrospray ionization mass spectrometry (ESI-MS) spectra were recorded on a Waters single quadrupole instrument SQ Detector, while high-resolution mass spectrometry (HR-MS) spectra were obtained with a Thermo Scientific Orbitrap LTQ-XL. Thin-layer chromatography (TLC) was performed on Merck 60 F254 silica gel, and flash column chromatography was performed on $230-400$ mesh Merck 60 silica gel.

Synthesis of 2,6-Diiodo-4-methoxypyridine 1-oxide (1). Prepared according to literature procedure ${ }^{14}$ from 4-methoxypyridine 1-oxide in $30 \%$ yield. ${ }^{1} \mathrm{H}$ NMR ( $\left.400 \mathrm{MHz}, \mathrm{CD}_{3} \mathrm{OD}\right): \delta 7.75(2 \mathrm{H}, \mathrm{s}, \mathrm{PyH} 3)$, $3.90\left(3 \mathrm{H}, \mathrm{s}, \mathrm{Py}-\mathrm{OCH}_{3}\right)$.

Synthesis of 2,6-Diiodo-4-methoxypyridine (2). Prepared according to literature procedure ${ }^{14}$ from 4-methoxy-pyridine 1-oxide in $90 \%$ yield. ${ }^{1} \mathrm{H}$ NMR (300 MHz, $\left.\mathrm{CD}_{3} \mathrm{OD}\right): \delta 7.42(2 \mathrm{H}, \mathrm{s}, \mathrm{PyH} 3), 3.86$ $\left(3 \mathrm{H}, \mathrm{s}, \mathrm{Py}-\mathrm{OCH}_{3}\right)$.

Synthesis of 4-Methoxy-2,6-bis((trimethylsilyl)ethynyl) pyridine (3). 2,6-Diiodo-4-methoxypyridine $(1.30 \mathrm{~g}, 3.60 \mathrm{mmol})$ is dissolved in a dry mixture of toluene and diisopropylamine $2: 1(150 \mathrm{~mL})$ under inert conditions. Then $\mathrm{CuI}(0.03 \mathrm{~g}, 0.15 \mathrm{mmol}), \mathrm{Pd}\left(\mathrm{PPh}_{3}\right)_{4}(0.08 \mathrm{~g}$, $0.07 \mathrm{mmol})$, and trimethylsilylacetylene $(0.82 \mathrm{~g}, 8.32 \mathrm{mmol})$ are added, and the reaction mixture is stirred at room temperature. After $24 \mathrm{~h}$ the reaction is quenched with water, and the aqueous phase is extracted with ethyl acetate $(\mathrm{AcOEt})$. The organic phases collected are dried over anhydrous $\mathrm{Na}_{2} \mathrm{SO}_{4}$, and the solvents are evaporated under reduced pressure. The crude is purified by flash column chromatography using hexane/AcOEt 8.5:1.5 as eluent. Yield: $92 \%$ ${ }^{1} \mathrm{H}$ NMR (400 MHz, $\left.\mathrm{CDCl}_{3}\right): \delta 6.95(2 \mathrm{H}, \mathrm{s}, \mathrm{PyH} 3)$, $3.87(3 \mathrm{H}, \mathrm{s}, \mathrm{Py}-$ $\left.\mathrm{OCH}_{3}\right), 0.27\left(18 \mathrm{H}, \mathrm{s}, \mathrm{Si}\left(\mathrm{CH}_{3}\right)_{3}\right) ;{ }^{13} \mathrm{C} \mathrm{NMR}\left(100 \mathrm{MHz}, \mathrm{CDCl}_{3}\right): \delta$ 165.7, 144.4, 113.2, 103.2, 94.8, 55.5, 0.3. mp 64-66 ${ }^{\circ} \mathrm{C}$.
Synthesis of 2,6-Diethynyl-4-methoxypyridine (4). One gram (3.32 mmol) of 4-methoxy-2,6-bis((trimethylsilyl)ethynyl) pyridine is dissolved in $70 \mathrm{~mL}$ of a mixture of $\mathrm{MeOH} / \mathrm{Et}_{2} \mathrm{O} 2: 1$, and then $2.3 \mathrm{~g}$ $(16.6 \mathrm{mmol})$ of $\mathrm{K}_{2} \mathrm{CO}_{3}$ is added. The reaction mixtures are stirred for $1 \mathrm{~h}$ and then quenched with water. The aqueous layer is extracted three times with AcOEt. The organic phases collected are dried over anhydrous $\mathrm{Na}_{2} \mathrm{SO}_{4}$, and then the solvent is removed under reduced pressure. The product is obtained as a brownish solid in $88 \%$ yield. ${ }^{1} \mathrm{H}$ NMR (400 MHz, $\left.\mathrm{CDCl}_{3}\right): \delta 7.01(2 \mathrm{H}, \mathrm{s}, \mathrm{PyH} 3), 3.88(3 \mathrm{H}, \mathrm{s}, \mathrm{Py}-$ $\left.\mathrm{OCH}_{3}\right), 3.13(2 \mathrm{H}, \mathrm{s}, \mathrm{CCH}) ;{ }^{13} \mathrm{C} \mathrm{NMR}\left(100 \mathrm{MHz}, \mathrm{CDCl}_{3}\right): \delta 165.8$, 143.7, 113.7, 82.1, 77.3, 55.6; HR-MS (ESI+) $\mathrm{m} / z$ : $[\mathrm{M}+\mathrm{H}]^{+}$Calcd for $\mathrm{C}_{10} \mathrm{H}_{8} \mathrm{NO} 158.0600$; Found $158.0601 ; \mathrm{mp} 140{ }^{\circ} \mathrm{C}$ dec.

Synthesis of 3-Azidopropan-1-ol. Prepared according to literature procedure. ${ }^{22}$ The $9.1 \mathrm{~g}(140 \mathrm{mmol})$ of $\mathrm{NaN}_{3}$ are added to $50 \mathrm{~mL}$ of water. When the azide is completely dissolved, $6.87 \mathrm{~g}(68 \mathrm{mmol})$ of 3chloropropan-1-ol are added dropwise. The reaction mixture is stirred at $80{ }^{\circ} \mathrm{C}$ for $24 \mathrm{~h}$. The aqueous solution is extracted three times with dichloromethane, and then the organic phases collected are dried over anhydrous $\mathrm{Na}_{2} \mathrm{SO}_{4}$. The solvent is evaporated in vacuo to obtain the product as a yellowish liquid. Yield: $85 \%{ }^{1} \mathrm{H}$ NMR $(400 \mathrm{MHz}$, $\left.\mathrm{CDCl}_{3}\right): \delta 3.76\left(2 \mathrm{H}, \mathrm{t}, J=6.0 \mathrm{~Hz}, \mathrm{CH}_{2} \mathrm{~N}_{3}\right), 3.46(2 \mathrm{H}, \mathrm{t}, J=6.6 \mathrm{~Hz}$, $\mathrm{CH}_{2} \mathrm{OH}$ ), $1.84\left(2 \mathrm{H}\right.$, quint, $J=6.3 \mathrm{~Hz}, \mathrm{CH}_{2} \mathrm{CH}_{2} \mathrm{CH}_{2}$ ). HR-MS (ESI +) $m / z:[\mathrm{M}+\mathrm{H}]^{+}$Calcd for $\mathrm{C}_{16} \mathrm{H}_{24} \mathrm{NOSi}_{2}$ 302.1391; Found 302.1392 .

Synthesis of PTD-OMe. The $0.25 \mathrm{~g}(1.59 \mathrm{mmol})$ of 2,6-diethynyl4-methoxypyridine and $0.52 \mathrm{~g}(5.2 \mathrm{mmol})$ of 3-azidopropan-1-ol are dissolved in $30 \mathrm{~mL}$ of a 1:1 mixture of water and ethanol. Then 7.5 $\mathrm{mg}(0.03 \mathrm{mmol})$ of $\mathrm{CuSO}_{4} \cdot 5 \mathrm{H}_{2} \mathrm{O}$ and $63.4 \mathrm{mg}(0.32 \mathrm{mmol})$ of sodium ascorbate are added. The reaction mixture is stirred for $3 \mathrm{~d}$ and then quenched by removal of the solvents under reduced pressure. The crude is purified by flash column chromatography using dichloromethane/methanol $92 / 8$ as eluent. The product was obtained as a white solid in $57 \%$ yield. ${ }^{1} \mathrm{H}$ NMR $\left(400 \mathrm{MHz}, \mathrm{CD}_{3} \mathrm{OD}\right): \delta 8.57$ $\left(2 \mathrm{H}, \mathrm{s}\right.$, Triaz-H), $7.53(2 \mathrm{H}, \mathrm{s}, \mathrm{PyH} 3), 4.62\left(4 \mathrm{H}, \mathrm{t}, J=7.2 \mathrm{~Hz}, \mathrm{CH}_{2} \mathrm{~N}\right)$, $4.00\left(3 \mathrm{H}, \mathrm{s}, \mathrm{Py}-\mathrm{OCH}_{3}\right), 3.64\left(4 \mathrm{H}, \mathrm{t}, J=6.0 \mathrm{~Hz}, \mathrm{CH}_{2} \mathrm{OH}\right), 2.20(4 \mathrm{H}$, quint, $\left.J=6.4 \mathrm{~Hz}, \mathrm{CH}_{2} \mathrm{CH}_{2} \mathrm{~N}\right) .{ }^{13} \mathrm{C} \mathrm{NMR}\left(100 \mathrm{MHz}, \mathrm{CD}_{3} \mathrm{OD}\right): \delta$ 167.6, 151.3, 147.6, 123.6, 104.7, 57.9, 54.8, 32.6. ESI-MS (+): 382.3 $[\mathrm{M}+\mathrm{Na}]^{+}, 398.2[\mathrm{M}+\mathrm{K}]^{+}, 558.9[\mathrm{M}+\mathrm{Na} \text { ascorbate }]^{+}, 741.5[2 \mathrm{M}$ $+\mathrm{Na}]^{+}$. HR-MS (ESI+) $m / z:[\mathrm{M}+\mathrm{H}]^{+}$Calcd for $\mathrm{C}_{16} \mathrm{H}_{22} \mathrm{~N}_{7} \mathrm{O}_{3}$ 360.1779; Found 360.1786. mp: $118-120^{\circ} \mathrm{C}$.

Solvent Extraction. Organic phase was $0.2 \mathrm{~mol} / \mathrm{L} N, N, N^{\prime}, N^{\prime}$ tetra- $n$-octyl-3-oxapentanediamide (TODGA) $)^{23-27}+5$ vol \% 1 octanol in kerosene. Aqueous phase was $80 \mathrm{mmol} / \mathrm{L}$ PTD or PTD$\mathrm{OMe}$ in $\mathrm{HNO}_{3}$ (varied concentration) spiked with each $2.5 \mathrm{kBq} / \mathrm{mL}$ ${ }^{241} \mathrm{Am}(\mathrm{III})$ and ${ }^{154} \mathrm{Eu}(\mathrm{III})$.

Each $300 \mu \mathrm{L}$ of aqueous and organic phases were placed in $2 \mathrm{~mL}$ Eppendorf tubes and shaken on an orbital shaker for $60 \mathrm{~min}$ at 1100 $\mathrm{rpm}$ and $295 \mathrm{~K}$. Following centrifugation for $10 \mathrm{~min}$ at $1000 \mathrm{rpm}, 200$ $\mu \mathrm{L}$ aliquots of both phases were analyzed on a gamma counter (Packard Cobra Auto-Gamma 5003). 
TRLFS Sample Preparation. Stock solutions containing $0.5 \mathrm{~mol} /$ L PTD-OMe were prepared by dissolving $50.3 \mathrm{mg}$ of PTD-OMe in

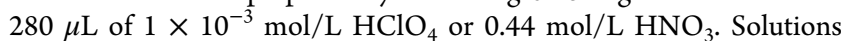
with lower PTD-OMe concentrations were prepared by dilution with $1 \times 10^{-3} \mathrm{~mol} / \mathrm{L} \mathrm{HClO}_{4}$ or $0.44 \mathrm{~mol} / \mathrm{L} \mathrm{HNO}_{3}$, respectively.

TRLFS samples were prepared by adding $4.7 \mu \mathrm{L}$ of a $\mathrm{Cm}$ (III) stock solution $\left(2.12 \times 10^{-5} \mathrm{~mol} / \mathrm{L} \mathrm{Cm}\left(\mathrm{ClO}_{4}\right)_{3}\right.$ in $0.1 \mathrm{~mol} / \mathrm{L} \mathrm{HClO}_{4}$; ${ }^{248} \mathrm{Cm}$ : 89.7\%, ${ }^{246} \mathrm{Cm}: 9.4 \%,{ }^{243} \mathrm{Cm}: 0.4 \%,{ }^{244} \mathrm{Cm}: 0.3 \%,{ }^{245} \mathrm{Cm}: 0.1 \%$,

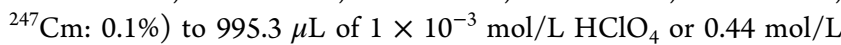
$\mathrm{HNO}_{3}$, resulting in an initial $\mathrm{Cm}(\mathrm{III})$ concentration of $1 \times 10^{-7} \mathrm{~mol} /$ L. Ligand concentration was adjusted by adding appropriate volumes of the PTD-OMe solutions. TRLFS spectra were recorded following an equilibration time of $10 \mathrm{~min}$. Preliminary tests showed this to be sufficient to attain equilibrium.

Solvent extraction samples for TRLFS measurements were prepared as described in Solvent Extraction, with the exception that samples were $500 \mu \mathrm{L}$ per phase each spiked with $4.7 \mu \mathrm{L}$ of the $\mathrm{Cm}$ (III) stock solution instead of ${ }^{241} \mathrm{Am}$ and ${ }^{154} \mathrm{Eu}$.

TRLFS Measurements. TRLFS measurements were performed at $298 \mathrm{~K}$ using a Nd:YAG (Surelite II laser, Continuum) pumped dye laser system (NarrowScan D-R; Radiant Dyes Laser Accessories $\mathrm{GmbH})$. A wavelength of $396.6 \mathrm{~nm}$ was chosen to excite $\mathrm{Cm}$ (III). A spectrograph (Shamrock 303i, ANDOR) with 300, 1199, and 2400 lines per millimeter gratings was used for spectral decomposition. The fluorescence emission was detected by an ICCD camera (iStar Gen III, ANDOR) after a delay time of $1 \mu$ s to discriminate short-lived, organic fluorescence, and light scattering.

NMR Sample Preparation. NMR samples for $\mathrm{p} K_{\mathrm{a}}$ determination contained initially $9 \times 10^{-3} \mathrm{~mol} / \mathrm{L}$ PTD-OMe in an aqueous formic acid/formate buffer containing 10 vol $\%$ of $\mathrm{D}_{2} \mathrm{O} . \mathrm{pH}$ was measured with a microelectrode (Orion PerpHecT ROSS, Thermo Fisher Scientific) and a $\mathrm{pH}$ meter (Orion Star, Thermo Fisher Scientific) before and after NMR measurement. The $\mathrm{pH}$ was adjusted with 1 , 0.1 , or $0.01 \mathrm{~mol} / \mathrm{L} \mathrm{HCl}$ or $\mathrm{NaOH}$ solutions.

NMR Measurements. NMR spectra were recorded at $T=300 \mathrm{~K}$ on a Bruker Avance III 400 spectrometer operating at a resonance frequency of $400.18 \mathrm{MHz}$ for ${ }^{1} \mathrm{H}$ nuclei. The spectrometer was equipped with a z-gradient observe room-temperature probe. Chemical shifts were referenced internally to tetramethylsilane (TMS) $(\delta($ TMS $)=0 \mathrm{ppm})$ by the deuterium lock signal of $\mathrm{D}_{2} \mathrm{O}$. For single scan ${ }^{1} \mathrm{H}$ spectra, standard $90^{\circ}$ pulse sequences were used. Water suppression was achieved by the WATERGATE ${ }^{28,29}$ pulse sequence. All spectra were recorded with $32 \mathrm{k}$ data points and were zero filled to $64 \mathrm{k}$ points. For WATERGATE spectra, eight scans were acquired per spectrum with a relaxation delay of $2 \mathrm{~s}$. Exponential window functions with a line broadening factor of $0.05 \mathrm{~Hz}$ were applied for processing.

Theoretical Model. Protonation and the complex formation of PTD-OMe were investigated. Structures were optimized employing density functional theory at the $\mathrm{B} 3-\mathrm{LYP}^{30} / \mathrm{def} 2-\mathrm{TZVP}^{31}$ level of theory as implemented in the TURBOMOLE ${ }^{32}$ program package. To avoid the known problem of spin contamination in Gd(III) complexes computed by the B3-LYP functional, the $\mathrm{BH}-\mathrm{LYP}^{33}$ functional was used instead on all metal ion complexes. NMR shielding constants were calculated for all atoms of unprotonated and protonated PTDOMe using the MPSHIFT ${ }^{34}$ routine in TURBOMOLE. Binding energies corrected for basis set superposition error (BSSE) of $\left[\mathrm{M}(\mathrm{PTD}-\mathrm{OMe})_{3}\right]^{3+}$ and $\left[\mathrm{M}(\mathrm{PTD})_{3}\right]^{3+}$ were determined on the MP2/def2-TZVP level, which was shown to yield good results when comparing to experimental separation factors (SF). ${ }^{35}$ The $\mathrm{Cm}(\mathrm{III})$ ion was described by a ECP $60 \mathrm{MWB}^{36}$ small-core pseudopotential, and the $\mathrm{Gd}(\mathrm{III})$ was described by an ECP28MWB ${ }^{36}$ small-core pseudopotential. Differences in selectivity have recently been connected to atomic polarizabilities of the coordinating atoms. ${ }^{37}$ To investigate the ligands at hand within this approach, atomic charges and dipole polarizabilities were calculated on the B3LYP/aug-ccpVTZ $^{38}$ level using the Hirshfeld method. ${ }^{37,39}$

\section{RESULTS AND DISCUSSION}

Solvent Extraction. The solvent extraction behavior of PTD-OMe was studied using Am(III) and Eu(III) as representatives for trivalent actinides and lanthanides. Figure 1 compares distribution ratios $\left(D_{\mathrm{M}(\mathrm{III})}=[\mathrm{M}(\mathrm{III})]_{\mathrm{org}} /[\mathrm{M}\right.$ -

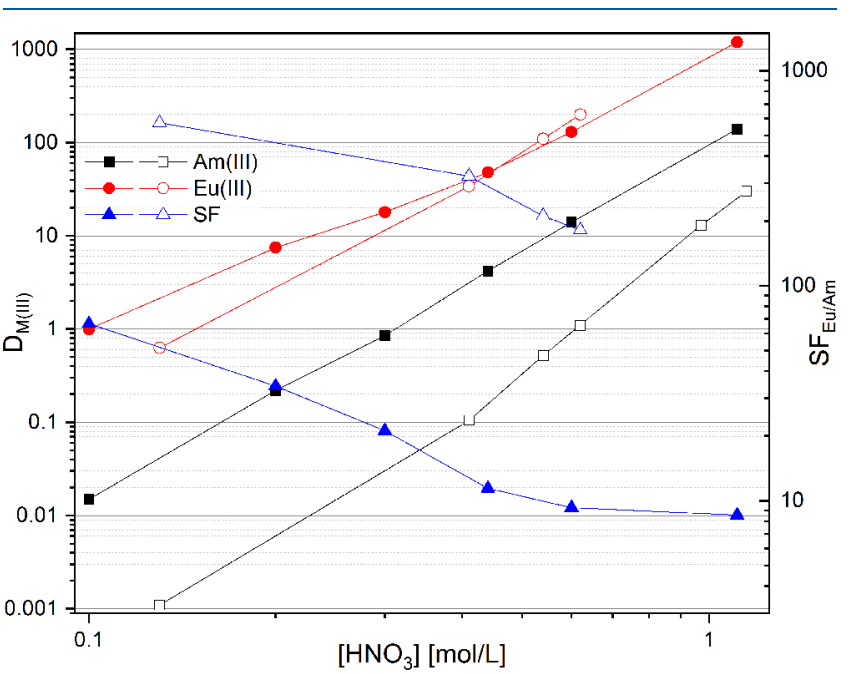

Figure 1. Distribution ratios for the extraction of $\mathrm{Am}(\mathrm{III})$ and $\mathrm{Eu}(\mathrm{III})$ with TODGA/PTD-OMe (solid symbols) and TODGA/PTD (open symbols). Organic phase, $0.2 \mathrm{~mol} / \mathrm{L}$ TODGA in TPH/1-octanol (5 vol \%). Aqueous phase, $0.08 \mathrm{~mol} / \mathrm{L}$ PTD-OMe or PTD in nitric acid. $A / O=1, T=295 \mathrm{~K}$.

(III) $\left.]_{\mathrm{aq}}\right)$ and separation factors $\left(\mathrm{SF}=D_{\mathrm{Eu}(\mathrm{III})} / D_{\mathrm{Am}(\mathrm{III})}\right)$ for the systems TODGA/PTD and TODGA/PTD-OMe as a function of nitric acid concentration.

$\mathrm{Am}(\mathrm{III}) / \mathrm{Eu}(\mathrm{III})$ separation is achieved for $D_{\mathrm{Am}(\mathrm{III})}<1$ and $D_{\mathrm{Eu}(\mathrm{III})}>1$. With PTD, this is the case at $0.15-0.6 \mathrm{~mol} / \mathrm{L}$ nitric acid, with a selectivity in the range of $500>$ SF $>180$. With PTD-OMe, separation is achieved at $0.1-0.3 \mathrm{~mol} / \mathrm{L}$ nitric acid, with a selectivity in the range of $60>\mathrm{SF}>20$. Contrary to expectation, PTD-OMe is a less efficient ligand compared to PTD.

Determination of the $\mathrm{p} K_{\mathrm{a}}$ Value by NMR. The insertion of an activating -OMe group on the pyridine nucleus of the ligand will impact the $\mathrm{p} K_{\mathrm{a}}$ value. Therefore, the $\mathrm{p} K_{\mathrm{a}}$ value of PTD-OMe was determined by evaluating the shifts of its ${ }^{1} \mathrm{H}$ NMR signals as a function of the measured $\mathrm{pH}$. Note that the ionic strength is not constant during titration. Because of the rather low ionic strength $\left(10^{-2}\right.$ to $\left.10^{-1} \mathrm{~mol} / \mathrm{L}\right)$, however, no corrections for the $\mathrm{pH}$ were performed. Corresponding ${ }^{1} \mathrm{H}$ NMR spectra at different $\mathrm{pH}$ values are shown in Figure 2.

The ${ }^{1} \mathrm{H}$ NMR signals of PTD-OMe show a downfield shift with decreasing $\mathrm{pH}$ due to protonation of the ligand. The ${ }^{1} \mathrm{H}$ NMR signals shift in a $\mathrm{pH}$ range of $4.02-1.25$. No shifts are observed beyond this range, indicating the existence of only the protonated or unprotonated ligand. Both species are characterized as follows (for proton assignment see Figure 3):

- Unprotonated PTD-OMe $(\mathrm{pH}=4.39):{ }^{1} \mathrm{H}$ NMR (400.18 MHz in formic acid/formate buffer +10 vol \% $\left.\mathrm{D}_{2} \mathrm{O}\right): \delta 8.20$ (s, 2H, H-1); 6.93 (s, 2H, H-3); 3.65 (s, $3 \mathrm{H}, \mathrm{H}-2) ; 3.58\left(\mathrm{t},{ }^{3} \mathrm{~J}_{\mathrm{H}-\mathrm{H}}=6.30 \mathrm{~Hz}, 4 \mathrm{H}, \mathrm{H}-6\right) ; 2.09$ (quint, ${ }^{3} \mathrm{~J}_{\mathrm{H}-\mathrm{H}}=6.68 \mathrm{~Hz}, 4 \mathrm{H}, \mathrm{H}-5$ ).

- Protonated PTD-OMe (pH = 0.96): ${ }^{1} \mathrm{H}$ NMR (400.18 $\mathrm{MHz}$ in formic acid/formate buffer +10 vol $\left.\% \mathrm{D}_{2} \mathrm{O}\right): \delta$ 8.75 (s, 2H, H-1); 7.65 (s, 2H, H-3); 4.12 (s, 3H, H-2); 


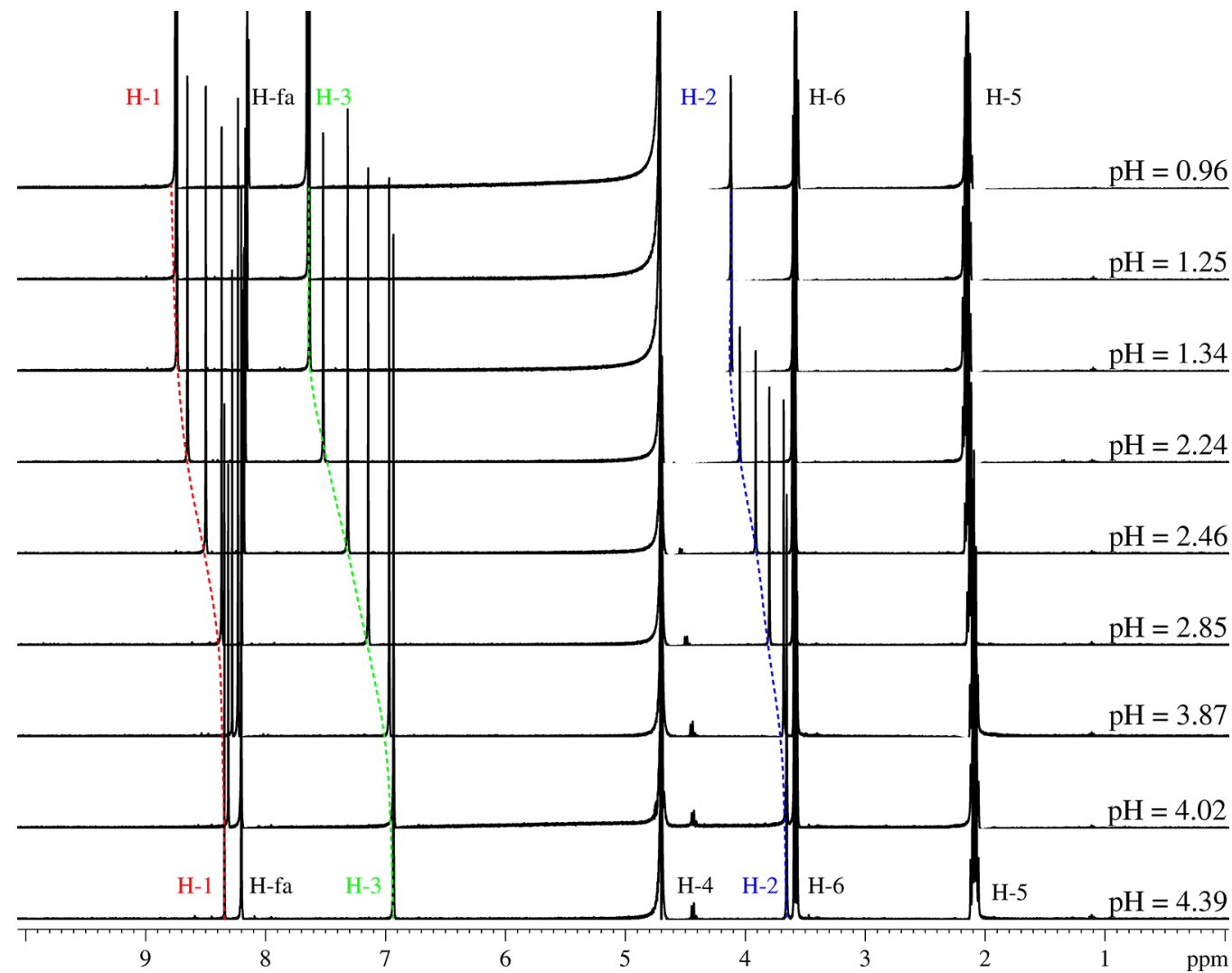

Figure 2. ${ }^{1} \mathrm{H}$ NMR spectra of PTD-OMe in formic acid/formate ( $\left.\mathrm{H}-\mathrm{fa}\right)$ buffer with $10 \mathrm{vol} \% \mathrm{D}_{2} \mathrm{O}$ at varied $\mathrm{pH}$. The water signal at $\delta=4.702 \mathrm{ppm}$ was suppressed using the WATERGATE technique.

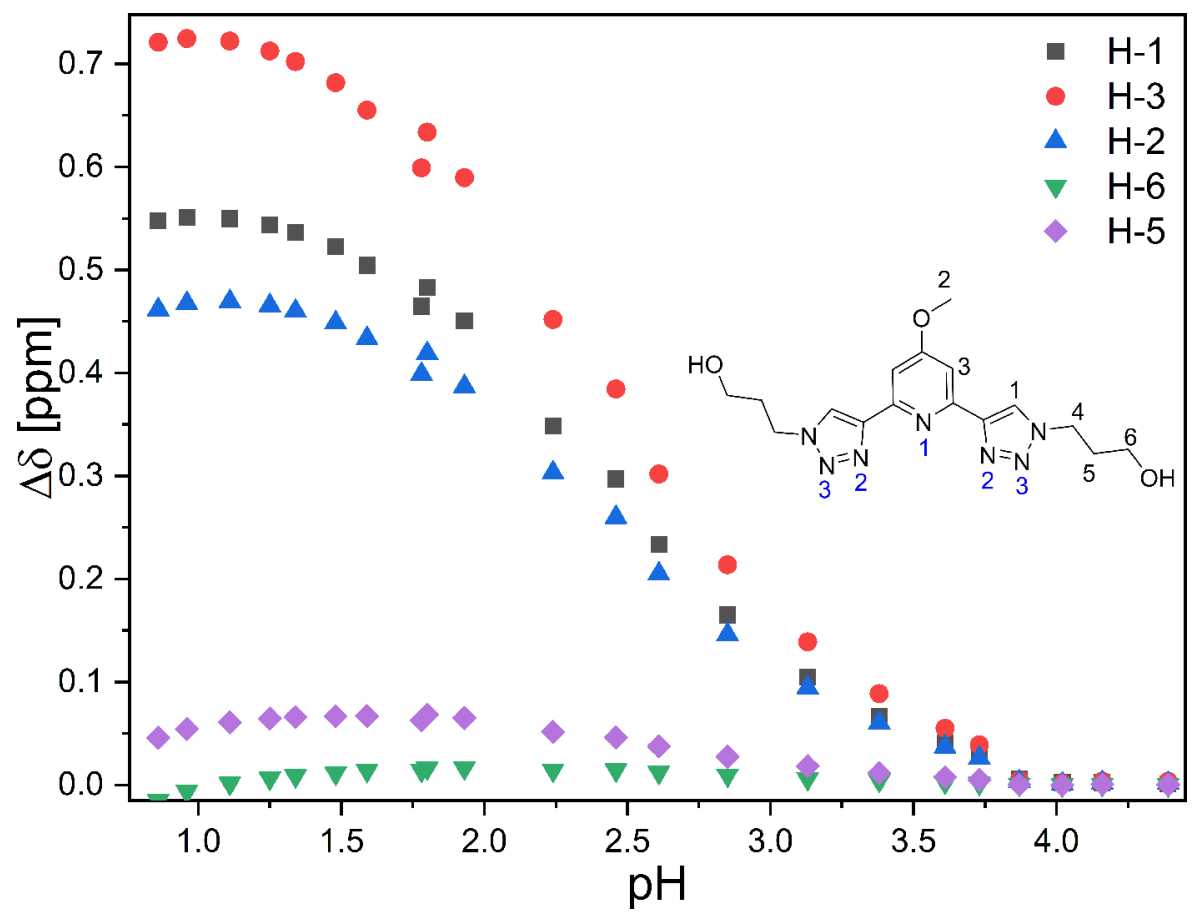

Figure 3. Shift of the ${ }^{1} \mathrm{H}$ signals in respect to the ${ }^{1} \mathrm{H}$ shift of the unprotonated $\mathrm{PTD}-\mathrm{OMe}$ as a function of $\mathrm{pH}$.

$3.57\left(\mathrm{t},{ }^{3} \mathrm{~J}_{\mathrm{H}-\mathrm{H}}=6.21 \mathrm{~Hz}, 4 \mathrm{H}, \mathrm{H}-6\right) ; 2.14\left(\right.$ quint, ${ }^{3} \mathrm{~J}_{\mathrm{H}-\mathrm{H}}=$ $6.55 \mathrm{~Hz}, 4 \mathrm{H}, \mathrm{H}-5)$.

Spectra in the $\mathrm{pH}$ range of $1.25-3.87$ contain both protonated and unprotonated species. The presence of only one set of ${ }^{1} \mathrm{H}$ signals indicates fast proton exchange, and, therefore, only an average of the signals of the two species is detected. Consequently, the peak shift $\left(\Delta \delta_{\mathrm{i}}\right.$, eq 1$)$ at a given $\mathrm{pH}$ relative to the shift of the unprotonated species $\left(\delta_{0}=\right.$ $\left.\delta_{\mathrm{pH}=4.39}\right)$ is used for $\mathrm{p} K_{\mathrm{a}}$ determination. The relative peak shifts for all protons of PTD-OMe are shown in Figure 3. 


$$
\Delta \delta_{i}=\delta_{i}-\delta_{0}
$$

With decreasing $\mathrm{pH}$, aromatic protons shift more strongly downfield than protons farther away from the aromatic center. The strongest shifts are observed for the pyridine protons $(\mathrm{H}$ 3; $\left.\Delta \delta_{\max }=0.725 \mathrm{ppm}\right)$, followed by the triazole protons $(\mathrm{H}-1$; $\left.\Delta \delta_{\max }=0.552 \mathrm{ppm}\right)$ and the methoxy protons $\left(\mathrm{H}-2 ; \Delta \delta_{\max }=\right.$ $0.470 \mathrm{ppm}$ ). Shifts of the protons $\mathrm{H}-5$ and $\mathrm{H}-6$ of the propanol units are negligible. The shift of the proton $\mathrm{H}-4$ cannot be evaluated due to the WATERGATE method. The strong shifts of the protons in the aromatic region indicate protonation in the aromatic region and most probably on the pyridine nucleus.

To determine the $\mathrm{p} K_{\mathrm{a}}$ value, proton signals $\mathrm{H} 1, \mathrm{H} 2$, and $\mathrm{H} 3$ were evaluated individually. With eq 2 , relative concentrations were calculated. The species distribution is given in the Supporting Information, Figure S1.

$$
\chi_{i}=\frac{\Delta \delta_{i}}{\Delta \delta_{\max }}
$$

The Henderson-Hasselbalch eq 3 was used to determine the $\mathrm{p} K_{\mathrm{a}}$ value of PTD-OMe.

$$
\log \left(\frac{\left[\mathrm{LH}_{n}^{n+}\right]}{[\mathrm{L}]}\right)=-n \times \mathrm{pH}+\mathrm{p} K_{\mathrm{a}}
$$

Slope analyses of $\mathrm{H}-1, \mathrm{H}-2$, and $\mathrm{H}-3$ shifts as a function of $\mathrm{pH}$ are shown in the Supporting Information, Figure S2. Slopes (see Table 1) of -1 confirm that one proton is transferred. $\mathrm{p} K_{\mathrm{a}}$

Table 1. Slopes and $\mathrm{p} K_{\mathrm{a}}$ Values for the Protonation of PTDOMe

$\begin{array}{ccc}\text { proton } & \text { slope } & \mathrm{pK} \\ \mathrm{H}-1 & -1.06 \pm 0.03 & 2.55 \pm 0.05 \\ \mathrm{H}-2 & -1.06 \pm 0.03 & 2.51 \pm 0.03 \\ \mathrm{H}-3 & -1.03 \pm 0.03 & 2.57 \pm 0.06\end{array}$

values derived from the shifts of $\mathrm{H}-1, \mathrm{H}-2$, and $\mathrm{H}-3$ are reported in Table 1 . The average $\mathrm{p} K_{\mathrm{a}}$ of PTD-OMe has a value of $2.54 \pm 0.08$. The attachment of a methoxy group, as expected for an electron-donating moiety, to the pyridine core results in a slightly increased basicity compared to PTD $\left(\mathrm{p} K_{\mathrm{a}}=\right.$ 2.1). ${ }^{14}$

Complexation of $\mathrm{Cm}(\mathrm{III})$ with PTD-OMe at $\mathrm{pH}=3$. TRLFS was utilized to study the complexation of $\mathrm{Cm}$ (III) with PTD-OMe. Stability constants and the speciation in solution were determined. Because of its favorable spectroscopic properties, $\mathrm{Cm}$ (III) was used to represent $\mathrm{Am}$ (III). This is valid due to the similar chemical properties of both elements.

The evolution of the $\mathrm{Cm}$ (III) fluorescence spectra resulting from the ${ }^{6} \mathrm{D}_{7 / 2}^{\prime} \rightarrow{ }^{8} \mathrm{~S}_{7 / 2}^{\prime}$ transition is shown in Figure 4 as a function of the PTD-OMe concentration.

Without addition of PTD-OMe the emission band of the $\mathrm{Cm}$ (III) aqua ion is observed at $593.8 \mathrm{~nm} .{ }^{40}$ With addition of PTD-OMe new emission bands evolve at 600.1, 605.6, and $608.8 \mathrm{~nm}$. The bathochromic shift is explained by the increased splitting of the ${ }^{6} \mathrm{D}^{\prime}{ }_{7 / 2}$ state due to the complexation of $\mathrm{Cm}(\mathrm{III})$ with PTD-OMe. The emission bands are in excellent agreement with those of the $\mathrm{Cm}(\mathrm{PTD})_{n}$ complexes $(n=1-3)$ in $1 \times 10^{-3} \mathrm{~mol} / \mathrm{L} \mathrm{HClO}_{4},{ }^{17}$ indicating that the observed emission bands correspond to the $\mathrm{Cm}(\mathrm{PTD}-\mathrm{OMe})_{n}$ complexes $(n=1-3)$.

With single-component spectra of the $\mathrm{Cm}(\mathrm{PTD}-\mathrm{OMe})_{n}$ complexes obtained by peak deconvolution (Figure 5) and the respective fluorescence intensity factors ${ }^{13}\left(\mathrm{FI}_{1}=1, \mathrm{FI}_{2}=\right.$ 1.1 , and $\left.\mathrm{FI}_{3}=1.1\right)$, the species distribution of the [Cm(PTD$\left.\mathrm{OMe})_{n}\right]^{3+}$ complexes $(n=1-3)$ as a function of the free (i.e., unprotonated and uncomplexed) PTD-OMe concentration was derived (see Figure 6). The free ligand concentration was calculated using eq 4 with $[\mathrm{L}]_{0}$ being the initial ligand concentration, $\left[\mathrm{H}^{+}\right]_{0}$ the initial proton concentration, $K_{\mathrm{a}}$ the ligand protonation constant, and $\chi_{i}$ the relative fraction of the $\mathrm{Cm}$ (III) complex species present at a given ligand concentration.

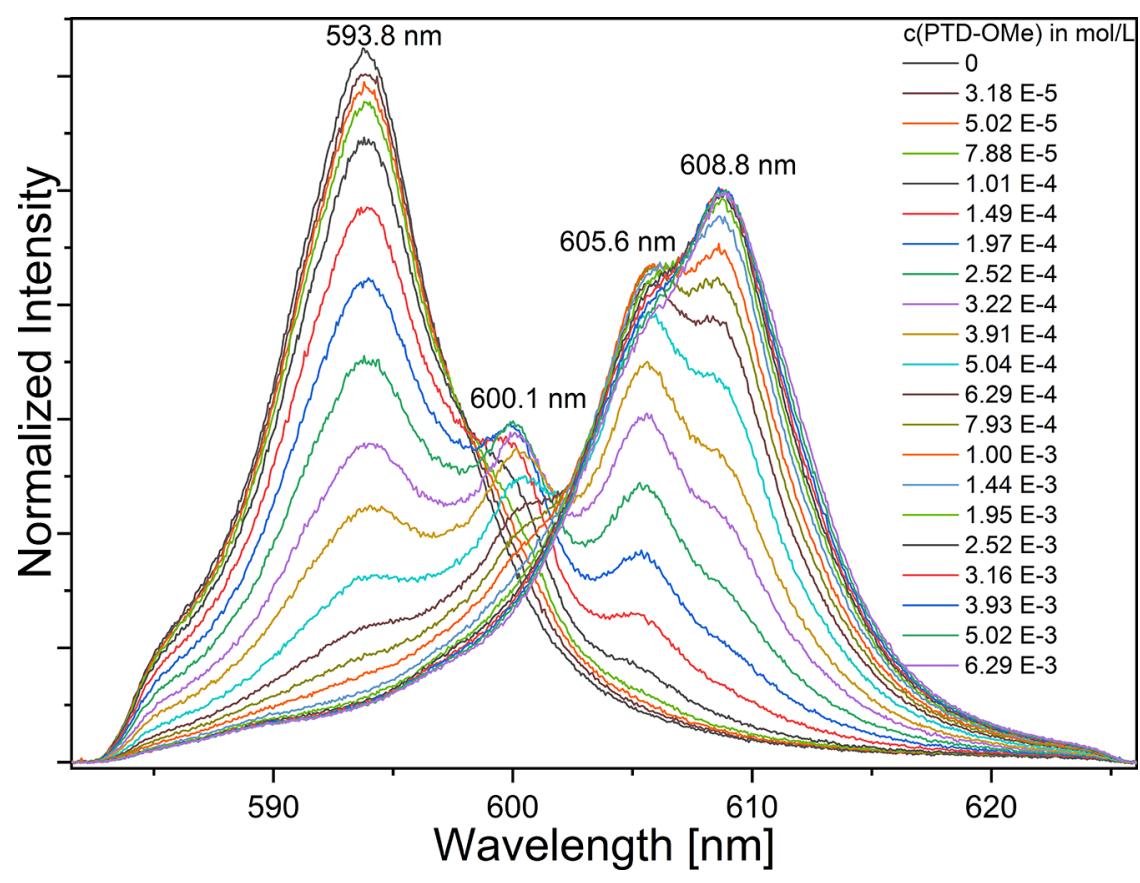

Figure 4. Normalized $\mathrm{Cm}(\mathrm{III})$ emission spectra in $1 \times 10^{-3} \mathrm{~mol} / \mathrm{L} \mathrm{HClO}_{4}$ with increasing PTD-OMe concentrations. $[\mathrm{Cm}]_{\mathrm{ini}}=1 \times 10^{-7} \mathrm{~mol} / \mathrm{L}$. 


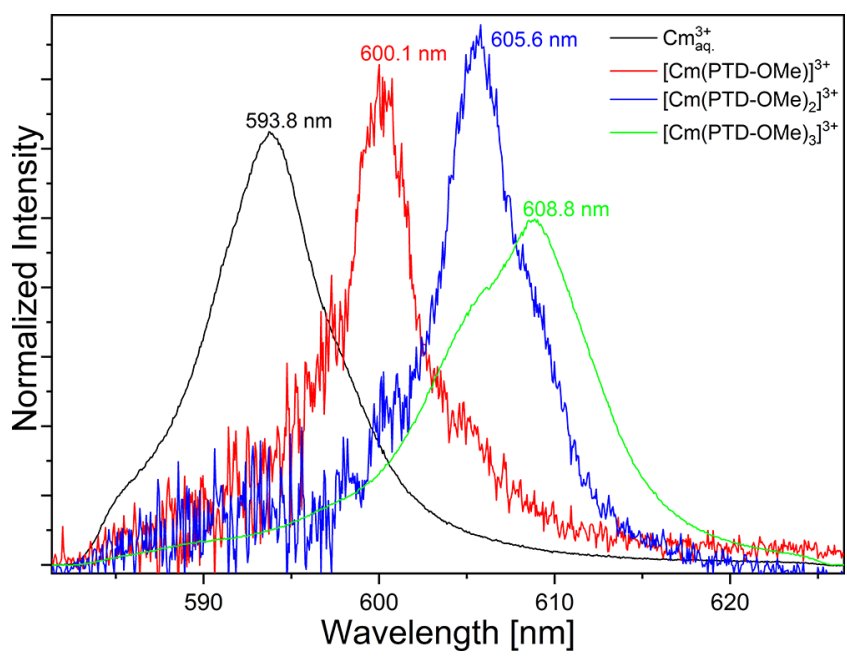

Figure 5. Normalized single-component spectra of the $[\mathrm{Cm}(\mathrm{PTD}-$ $\left.\mathrm{OMe})_{n}\right]^{3+}(n=0-3)$ complexes in $1 \times 10^{-3} \mathrm{~mol} / \mathrm{L} \mathrm{HClO}_{4}$.

$$
\begin{aligned}
{[\mathrm{L}]_{\text {free }}=} & 0.5 \times\left(\left(4 \times[\mathrm{L}]_{0} \times K_{\mathrm{a}}+\left[\mathrm{H}^{+}\right]_{0}^{2}+2 \times\left[\mathrm{H}^{+}\right]_{0}\right.\right. \\
& \left.\left.\times K_{\mathrm{a}}+K_{\mathrm{a}}{ }^{2}\right)^{0.5}-\left[\mathrm{H}^{+}\right]_{0}-K_{\mathrm{a}}\right) \\
& -\left([\mathrm{Cm}(\mathrm{III})] \times\left(\chi_{1: 1}+2 \times \chi_{1: 2}+3 \times \chi_{1: 3}\right)\right)
\end{aligned}
$$

The 1:1 complex starts forming at a PTD-OMe concentration of $\approx 10^{-5} \mathrm{~mol} / \mathrm{L}$, with a maximum of $23 \%$ at $2.5 \times 10^{-4}$ $\mathrm{mol} / \mathrm{L}$. The $1: 2$ complex has a maximum fraction of $26 \%$ at 5.3 $\times 10^{-4} \mathrm{~mol} / \mathrm{L}$ PTD-OMe. For PTD-OMe concentrations greater than $3.5 \times 10^{-4} \mathrm{~mol} / \mathrm{L}$ the $1: 3$ complex is the dominating species. The fluorescence lifetime $(\tau=495 \pm 20$ $\mu \mathrm{s})$ determined at a ligand concentration of $6.29 \times 10^{-3} \mathrm{~mol} / \mathrm{L}$ (see Figure S3) indicates the absence of water molecules in the first coordination sphere $\left(\mathrm{n}\left(\mathrm{H}_{2} \mathrm{O}\right)=0.4 \pm 0.5\right),{ }^{40}$ in agreement with full coordination by three PTD-OMe molecules.
To verify the stepwise complexation according to eq $5(\mathrm{~L}=$ PTD-OMe)

$$
\left[\mathrm{Cm}(\mathrm{L})_{n-1}\right]^{3+}+\mathrm{L} \leftrightharpoons\left[\mathrm{Cm}(\mathrm{L})_{n}\right]^{3+}(n=1-3)
$$

slope analyses were performed using eq 6, with the results shown in the Supporting Information, Figure S4.

$$
\log \left(\frac{\left[\mathrm{Cm}(\mathrm{L})_{n}\right]^{3+}}{\left[\mathrm{Cm}(\mathrm{L})_{n-1}\right]^{3+}}\right)=1 \times \log \left([\mathrm{L}]_{\text {free }}\right)+\log K_{n}^{\prime}
$$

Slopes of $m_{1}=1.13 \pm 0.06, m_{2}=0.98 \pm 0.15$, and $m_{3}=1.19 \pm$ 0.07 confirm the stepwise complexation according to eq 5 .

With eq 7 , conditional stability constants were determined: $\log \beta^{\prime}{ }_{1}=3.4 \pm 0.3, \log \beta^{\prime}{ }_{2}=7.0 \pm 0.4$, and $\log \beta^{\prime}{ }_{3}=10.8 \pm$ 0.4. Calculated and experimental relative fractions deviate slightly in the range from $1 \times 10^{-4}$ to $4 \times 10^{-4} \mathrm{~mol} / \mathrm{L}$. This is due to the lower signal-to-noise ratio of the single-component spectra of the 1:1 and 1:2 complexes used for peak deconvolution.

$$
\log \beta_{n}^{\prime}=\log \left(\frac{\left[\mathrm{Cm}(\mathrm{L})_{n}\right]^{3+}}{\left[\mathrm{Cm}_{\mathrm{aq}}\right]^{3+} \times[\mathrm{L}]_{\text {free }}^{n}}\right)
$$

TRLFS on Solvent Extraction Samples. To study the speciation under extraction conditions $\left(0.44 \mathrm{~mol} / \mathrm{L} \mathrm{HNO}_{3}\right)$, TRLFS was performed on both the aqueous and organic phases of a solvent extraction experiment.

The organic phase (Figure 7, top) shows the emission spectrum of the $\left[\mathrm{Cm}(\mathrm{TODGA})_{3}\right]^{3+}$ complex $^{17}$ with its characteristic emission band at $608.8 \mathrm{~nm}$ and a hot band at $595 \mathrm{~nm}$. The species is also verified by its fluorescence lifetime (see Supporting Information, Figure S5; $\tau=403 \pm 12 \mu \mathrm{s}$; $\left.\mathrm{n}\left(\mathrm{H}_{2} \mathrm{O}\right)=0.7 \pm 0.5\right)$, confirming coordination of three TODGA ligands.

In case of PTD, $80 \%$ of the $1: 3$ complex and $20 \%$ of the $1: 2$ complex are found under the extraction conditions $(0.44 \mathrm{~mol} /$ $\left.\mathrm{L} \mathrm{HNO}_{3}\right) \cdot{ }^{17}$ To observe a high selectivity in an extraction

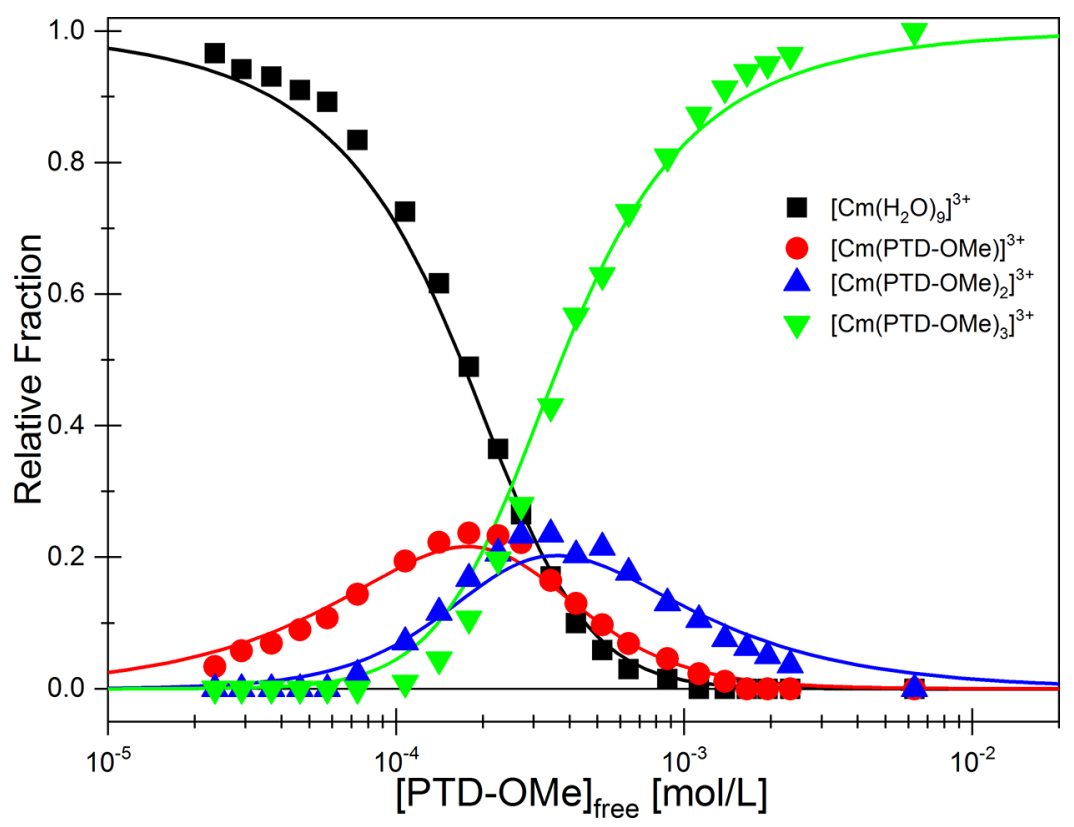

Figure 6. $\mathrm{Cm}(\mathrm{III})$ species distribution in $1 \times 10^{-3} \mathrm{~mol} / \mathrm{L} \mathrm{HClO}_{4}$ as a function of the free PTD-OMe concentration. Symbols, experimental data. Lines, calculated with $\log \beta^{\prime}{ }_{1}=3.4, \log \beta^{\prime}{ }_{2}=7.0$, and $\log \beta^{\prime}{ }_{3}=10.8$. 

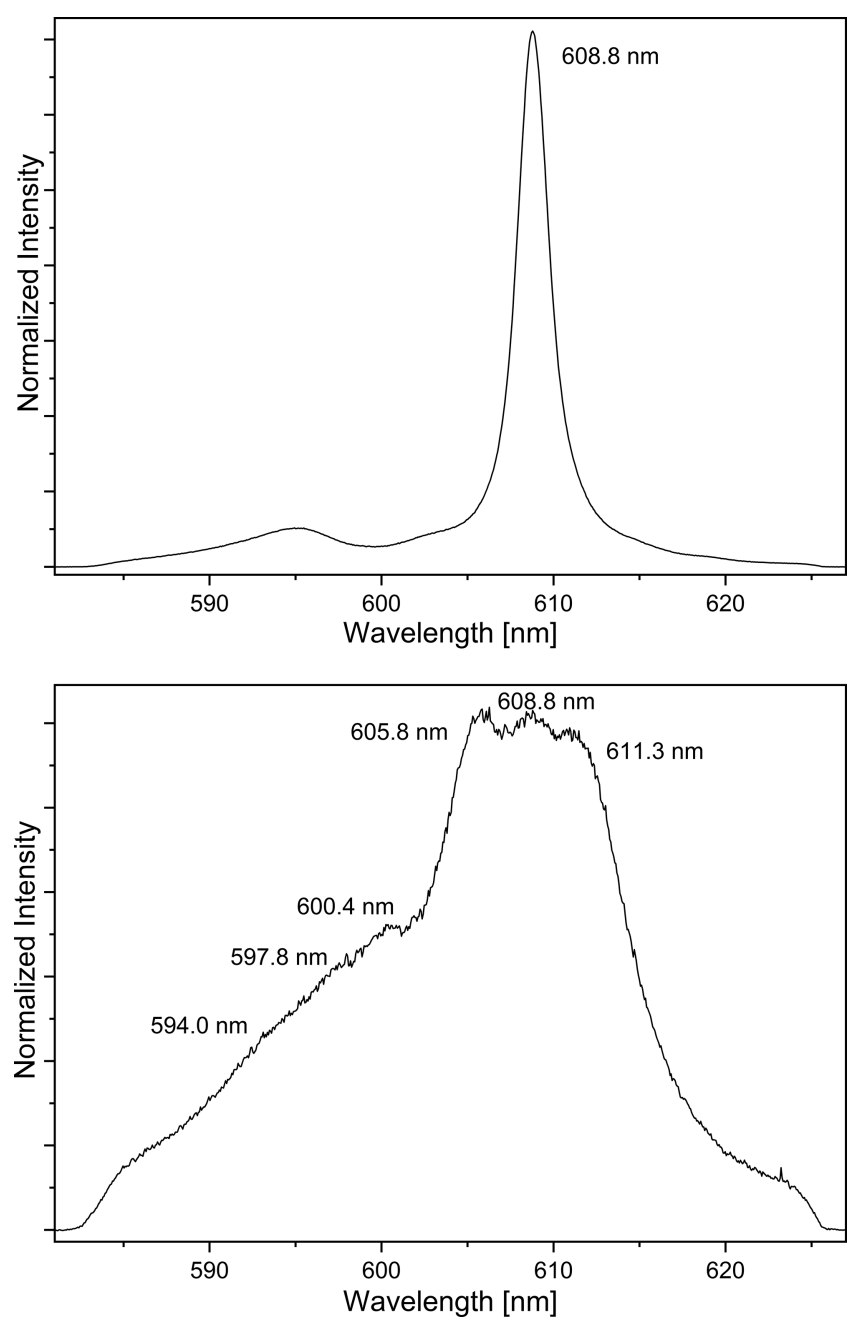

Figure 7. $\mathrm{Cm}$ (III) emission spectra of the organic (top) and aqueous (bottom) phases of a solvent extraction sample. Organic phase, 0.2 $\mathrm{mol} / \mathrm{L}$ TODGA in TPH/1-octanol (5 vol \%). Aqueous phase, $1 \times$ $10^{-7} \mathrm{~mol} / \mathrm{L} \mathrm{Cm}(\mathrm{III})$ and $0.08 \mathrm{~mol} / \mathrm{L}$ PTD-OMe in $0.44 \mathrm{~mol} / \mathrm{L}$ nitric acid.

experiment, however, the presence of only the $1: 3$ complex is mandatory. To improve the speciation in $0.44 \mathrm{~mol} / \mathrm{L} \mathrm{HNO}_{3}$ the methoxy group was introduced in PTD-OMe. Yet, multiple species are present in $0.44 \mathrm{~mol} / \mathrm{L} \mathrm{HNO}_{3}$ in case of PTD-OMe as shown by the emission spectrum of the aqueous phase (Figure 7, bottom) explaining the observed diminished selectivity of PTD-OMe.

Comparison of PTD-OMe and PTD. An overview of the conditional stability constants and $\mathrm{p} K_{\mathrm{a}}$ values of PTD-OMe and PTD is given in Table 2. The $\mathrm{p} K_{\mathrm{a}}$ value of PTD-OMe is $\approx 0.5$ higher than the $\mathrm{p} K_{\mathrm{a}}$ of $\mathrm{PTD}$. This higher basicity is in

Table 2. Conditional Stability Constants of the [Cm(PTDOMe $\left.)_{n}\right]^{3+}$ and $\left[\mathrm{Cm}(\mathrm{PTD})_{n}\right]^{3+}$ Complexes

\begin{tabular}{|c|c|c|}
\hline \multicolumn{2}{|c|}{ PTD-OMe } & PTD $^{17}$ \\
\hline \multicolumn{2}{|c|}{$\mathrm{p} K_{\mathrm{a}}=2.54$} & $\mathrm{p} K_{\mathrm{a}}=2.1$ \\
\hline$n$ & $\log \beta^{\prime}{ }_{n}$ & $\log \beta_{n}^{\prime}$ \\
\hline 1 & $3.4 \pm 0.3$ & $3.2 \pm 0.2$ \\
\hline 2 & $7.0 \pm 0.4$ & $6.8 \pm 0.2$ \\
\hline 3 & $10.8 \pm 0.4$ & $9.9 \pm 0.5$ \\
\hline
\end{tabular}

good agreement with the higher conditional stability constants observed for PTD-OMe compared to PTD. Stability constants for the lower complex species are less influenced by the activation of the aromatic core, whereas the conditional stability constant of the $1: 3$ complex is almost 1 order of magnitude higher for PTD-OMe. A linear correlation between stability constants and $\mathrm{p} K_{\mathrm{a}}$ values has been observed for many other systems. ${ }^{41,42}$ The results for PTD-OMe are in good agreement with this observed trend.

The higher basicity of PTD-OMe explains its inferior performance in extraction experiments compared to PTD. The free ligand concentration decreases due to the acidic conditions used in the extraction experiments $(0.44 \mathrm{~mol} / \mathrm{L}$ $\mathrm{HNO}_{3}$ ). Because of the higher $\mathrm{p} K_{\mathrm{a}}$ value of PTD-OMe, the concentration of unprotonated ligand is lower compared to that of PTD. Consequently, Am(III) distribution ratios are less favorable, that is, higher. Since N-donor ligands such as $\operatorname{PTD}(-$ $\mathrm{OMe}$ ) have lower affinity for $\mathrm{Eu}(\mathrm{III})$ compared to $\mathrm{Am}(\mathrm{III})$, $\mathrm{Eu}(\mathrm{III})$ distribution ratios are less affected, and hence selectivity is lower for PTD-OMe (cf. Figure 1).

As expected, the activation of the aromatic core of PTD made PTD-OMe a stronger ligand. However, in systems in which the $\mathrm{pH}$ is smaller than the $\mathrm{p} K_{\mathrm{a}}$ value the ligand with the lower $\mathrm{p} K_{\mathrm{a}}$ shows the better extraction performance, as the free ligand concentration is higher.

Quantum-Chemical Calculations. To support the experimental findings, various computational calculations were performed using DFT. The effect of the protonation on NMR shielding was investigated. The NMR spectra (see Figure 3) reveal the strongest downfield shift for the pyridine protons ( $\mathrm{H}-3)$, followed by the triazole $(\mathrm{H}-1)$ and methoxy $(\mathrm{H}-2)$ protons. For the latter, a static model representation is not able to capture the equivalency of the three methoxy protons. Hence, average values are reported in the following. To elucidate the site of protonation, various protonated structures of PTD-OMe were calculated and compared (Table 3).

Table 3. Energy Difference of the Different Optimized Protonated PTD-OMe Structures Relative to the Most Stable One ${ }^{a}$

$\begin{array}{cc}\text { site of protonation } & \Delta E[\mathrm{~kJ} / \mathrm{mol}] \\ \mathrm{H}-\mathrm{N}^{1} & 0 \\ \mathrm{H}-\mathrm{N}^{2} & 55.8 \\ \mathrm{H}-\mathrm{N}^{3} & 150.5 \\ \mathrm{H}-\mathrm{OMe} & 311.8 \\ \mathrm{H}-\mathrm{OH} & 311.2\end{array}$

${ }^{a}$ Calculated at B3-LYP/def2-TZVP level of theory. For atom assignment, see Figure 3.

The most favorable protonation energy is found for the pyridine nitrogen $\left(\mathrm{N}^{1}\right)$. The protonation of the coordinating nitrogen atoms of the triazole rings $\left(\mathrm{N}^{2}\right)$ is disfavored by 55.8 $\mathrm{kJ} / \mathrm{mol}$. The protonation of the other nitrogen atoms $\left(\mathrm{N}^{3}\right)$ or the oxygen donors is disfavored even more. Similar trends are reported for BTP-type ligands, where protonation also takes place at the pyridine nitrogen, but the protonation of the coordinating triazine nitrogen atoms is disfavored by only 25.1 $\mathrm{kJ} / \mathrm{mol}^{19,43,44}$

${ }^{1} \mathrm{H}$ NMR shifts were calculated to further support the site of protonation. $\Delta \delta_{\mathrm{i}}$ values (cf. equation 1) between the unprotonated PTD-OMe and all protonated PTD-OMe 
structures were calculated. Table 4 reports $\Delta \delta_{\text {i }}$ values for the protons of the pyridine ( $\mathrm{H}-3)$ and the triazole $(\mathrm{H}-1)$ ring and the methoxy group $(\mathrm{H}-2)$.

Table 4. Differences of the ${ }^{1} \mathrm{H}$-NMR Shifts between Different Protonated PTD-OMe and the Unprotonated PTD-OMe ${ }^{a}$

\begin{tabular}{lccccc} 
& \multicolumn{5}{c}{ site of protonation } \\
\cline { 2 - 6 } & $\mathrm{H}-\mathrm{N}^{1}$ & $\mathrm{H}^{-\mathrm{N}^{2}}$ & $\mathrm{H}-\mathrm{N}^{3}$ & $\mathrm{H}-\mathrm{OMe}$ & $\mathrm{H}-\mathrm{OH}$ \\
$\mathrm{H}-1$ (Tri) & 0.130 & 0.281 & 0.190 & 0.004 & -0.021 \\
$\mathrm{H}-2$ (OMe) & 0.326 & 0.157 & 0.166 & 1.106 & -0.015 \\
$\mathrm{H}-3$ (Py) & 0.267 & 0.176 & 0.172 & 0.120 & -0.221
\end{tabular}

${ }^{a} \Delta \delta_{\mathrm{i}}$ in analogy to equation 1 , calculated with the MPSHIFT package at B3-LYP/def2-TZVP level of theory.

Downfield shifts observed experimentally decrease in the order of $\Delta \delta_{\mathrm{H}-3}>\Delta \delta_{\mathrm{H}-1}>\Delta \delta_{\mathrm{H}-2}$. Note that, for the evaluation of the calculations, the shifts of $\mathrm{H}-2$ are not considered, as the methoxy groups rotate very quickly in solution, which leads to larger deviations of the calculations. Therefore, the trend $\Delta \delta_{\mathrm{H}-3}$ $>\Delta \delta_{\mathrm{H}-1}$ was evaluated. It was found only for the protonation at the pyridine nitrogen or the methoxy oxygen. Since the protonation of the methoxy oxygen is disfavored by $311.3 \mathrm{~kJ} /$ $\mathrm{mol}$ in all calculations, both protonation energies and ${ }^{1} \mathrm{H}$ shifts suggest the protonation of PTD-OMe to occur at the pyridine nitrogen.

Furthermore, the structures of the $1: 3$ complexes of $\mathrm{Cm}$ (III) and Gd(III) with PTD and PTD-OMe were optimized, and binding energies $(\mathrm{BE})$ of the complexes and atomic charges $(q)$ and dipole polarizabilities $(\alpha)$ of the coordinating nitrogen atoms $\left(\mathrm{N}^{1}\right.$ and $\left.\mathrm{N}^{2}\right)$ were calculated. It had been shown that dipole polarizabilities of ligands influence their selectivity. ${ }^{37}$ The calculated values are listed in Table 5 .

Introduction of the methoxy group does not affect the charge density $(q)$ within the pyridine ring in PTD-OMe compared to PTD but has a significant effect on the dipole polarizabilities $(\alpha)$ of all nitrogen atoms, both in the pyridine as well as the triazole ring. This effect is also reflected in the calculated bond distances between the metal ions and $N_{1}$ in the $\left[\mathrm{M}(\mathrm{PTD}-\mathrm{OMe})_{3}\right]^{3+}(\mathrm{M}=\mathrm{Cm}, \mathrm{Gd})$ complexes, in which the bond length decreases by $2 \mathrm{pm}$ in both complexes compared to PTD (cf. Supporting Information, Table S1).

According to theory, ${ }^{37} \mathrm{An}(\mathrm{III}) / \mathrm{Ln}$ (III) selectivity with respect to the dipole polarizabilities of $\mathrm{N}^{1}$ versus $\mathrm{N}^{2}$ for both PTD and PTD-OMe is plotted in Figure 8 with the optimal zone for high selectivity highlighted.

The dipole polarizabilities of PTD are within the optimal zone for high selectivity. On the basis of the atomic properties, a significant decrease in selectivity is expected for PTD-OMe. Accordingly, lower separation factors $\mathrm{SF}_{\mathrm{Cm} / \mathrm{Gd}}$ are expected to be obtained. To calculate $\mathrm{SF}_{\mathrm{Cm} / \mathrm{Gd}}$ values, an exchange reaction according to equation 8 was considered.

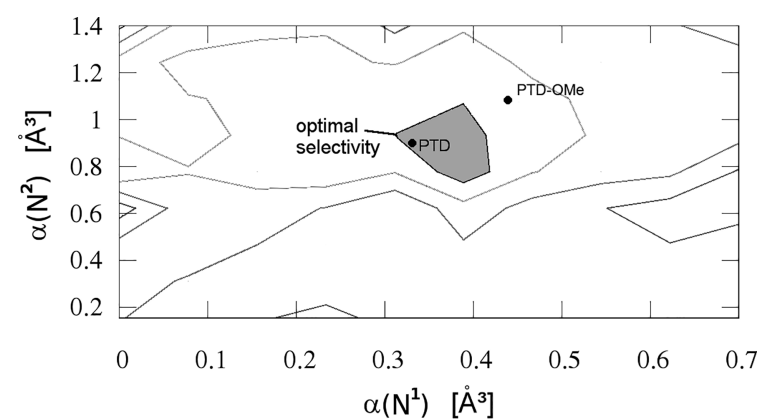

Figure 8. $\mathrm{An}(\mathrm{III}) / \mathrm{Ln}(\mathrm{III})$ selectivity for different $\mathrm{N}^{1} / \mathrm{N}^{2}$ polarizabilities according to ref 37 .

$$
\begin{aligned}
& {\left[\mathrm{GdL}_{3}\right]^{3+}+\left[\mathrm{Cm}\left(\mathrm{H}_{2} \mathrm{O}\right)_{9}\right]^{3+}} \\
& \rightleftharpoons\left[\mathrm{CmL}_{3}\right]^{3+}+\left[\mathrm{Gd}\left(\mathrm{H}_{2} \mathrm{O}\right)_{9}\right]^{3+} \\
& \Delta E_{\mathrm{g}}=\mathrm{BE}\left(\left[\mathrm{CmL}_{3}\right]^{3+}\right)-\mathrm{BE}\left(\left[\mathrm{GdL}_{3}\right]^{3+}\right) \\
& \mathrm{SF}_{\mathrm{Cm} / \mathrm{Gd}}=\exp \left(-\frac{\Delta E_{\mathrm{g}}-74.1 \frac{\mathrm{kJ}}{\mathrm{mol}}}{R T}\right)
\end{aligned}
$$

First, BE of the $1: 3$ complexes for $\mathrm{Gd}(\mathrm{III})$ and $\mathrm{Cm}$ (III) were calculated (Table 5). Although the BE for PTD-OMe complexes are higher in general, smaller differences $\left(\Delta E_{g}\right.$, eq 9) in the BE of the 1:3 PTD-OMe complexes of $\mathrm{Cm}(\mathrm{III})$ and $\mathrm{Gd}(\mathrm{III})$ were found compared to the corresponding PTD complexes. Separation factors were calculated using equation 10 taking into account a difference of $74.1 \mathrm{~kJ} / \mathrm{mol}$ between the corresponding aqua ions. ${ }^{35}$

The smaller difference in binding energy $\left(\Delta E_{\mathrm{g}}\right)$ of PTDOMe leads to a decrease in selectivity by a factor of 5 from a calculated separation factor $\left(\mathrm{SF}_{\mathrm{Cm} / \mathrm{Gd}}\right)$ of 31 for PTD to 6 for PTD-OMe. This is in good agreement with experimental findings $\left(\mathrm{SF}_{\mathrm{Am} / \mathrm{Eu}}(\mathrm{PTD})_{\text {exp. }}=100-36 ; \mathrm{SF}_{\mathrm{Am} / \mathrm{Eu}}(\mathrm{PTD}-\mathrm{OMe})_{\text {exp. }}\right.$ $=12-4)$. Note that experimentally determined separation factors reflect the selectivity of both PTD and TODGA, with the $\mathrm{Gd}(\mathrm{III}) / \mathrm{Cm}(\mathrm{III})$ selectivity of TODGA being $\sim 5 .^{6}$

\section{CONCLUSION}

Hoping to improve the extraction and complexation properties of PTD, a water-soluble complexing agent, PTD-OMe was synthesized. By placing a methoxy moiety at the 4-position of the central pyridine the aromatic core was activated. To study the impact of this activation the $\mathrm{p} K_{\mathrm{a}}$ and the speciation in aqueous and acidic solutions were investigated.

The $\mathrm{p} K_{\mathrm{a}}$ of PTD-OMe was determined using NMR. PTDOMe $\left(\mathrm{p} K_{\mathrm{a}}=2.54 \pm 0.08\right)$ is more prone to protonation than PTD $\left(\mathrm{pK}_{\mathrm{a}}=2.1\right)$. Consequently, greater stability constants were expected $^{41,42}$ for the metal ion complexes with PTDOMe. TRLFS confirmed the conditional stability constant of

\begin{tabular}{|c|c|c|c|c|c|c|c|}
\hline & \multicolumn{2}{|c|}{$\mathrm{N}^{1}$} & \multicolumn{2}{|c|}{$\mathrm{N}^{2}$} & \multirow[b]{2}{*}{$\mathrm{BE}(\mathrm{Cm})[\mathrm{kJ} / \mathrm{mol}]$} & \multirow[b]{2}{*}{$\mathrm{BE}(\mathrm{Gd})[\mathrm{kJ} / \mathrm{mol}]$} & \multirow[b]{2}{*}{$\mathrm{SF}_{\mathrm{Cm} / \mathrm{Gd}}$} \\
\hline & $q[\mathrm{e}]$ & $\alpha\left[\AA^{3}\right]$ & $q[\mathrm{e}]$ & $\alpha\left[\AA^{3}\right]$ & & & \\
\hline PTD & -0.13 & 0.32 & -0.12 & 0.93 & -3292.3 & -3357.9 & 33 \\
\hline PTD-OMe & -0.14 & 0.42 & -0.12 & 1.10 & -3404.7 & -3474.3 & 6 \\
\hline
\end{tabular}
the $\mathrm{Cm}$ (III) 1:3 complex to be almost 1 order of magnitude

Table 5. Calculated Atomic Charges (q), Dipole Polarizabilities ( $\alpha$ ), Binding Energies (BE), and Separation Factors (SF) of Cm(III) and Gd(III) 1:3 Complexes 
greater for PTD-OMe $\left(\log \beta_{3}(\mathrm{PTD}-\mathrm{OMe})=10.8 \pm 0.4\right)$ than for PTD $\left(\log \beta_{3}(\mathrm{PTD})=9.9 \pm 0.5\right)$.

Unfortunately, in solvent extraction experiments (involving $0.44 \mathrm{~mol} / \mathrm{L}$ nitric acid in the aqueous phase) PTD-OMe performed inferior to PTD. This was due to the smaller amount of free ligand present under the used solvent extraction conditions, although it was the stronger ligand. Therefore, protonation outcompeted complexation under solvent extraction conditions.

NMR experimental data and DFT calculations confirmed protonation of PTD-OMe to occur at the pyridine nitrogen atom. The lower selectivity of PTD-OMe compared to PTD was explained by an increased polarizability of the coordinating nitrogen atoms, actually leaving the small zone of optimum polarizability.

Clearly, the positive effect of methoxy substitution observed for some lipophilic N-heterocyclic extracting agents ${ }^{19-21}$ is overcompensated by increased susceptibility to protonation in the case of the water-soluble PTD complexing agents.

\section{ASSOCIATED CONTENT}

\section{S Supporting Information}

The Supporting Information is available free of charge on the ACS Publications website at DOI: 10.1021/acs.inorgchem.9b02325.

Slope analyses, species distribution for the $\mathrm{p} K_{\mathrm{a}}$ determination, and $\mathrm{Cm}(\mathrm{III})$ fluorescence lifetime measurements not shown in the manuscript (PDF)

\section{AUTHOR INFORMATION}

\section{Corresponding Authors}

*E-mail: patrik.wessling@kit.edu. (P.W.)

*E-mail: alessandro.casnati@unipr.it. (A.C.)

*E-mail: elena.macerata@polimi.it. (E.M.)

\section{ORCID}

Patrik Weßling: 0000-0002-4410-5344

Christian Adam: 0000-0003-1449-7065

\section{Author Contributions}

All authors have given approval to the final version of the manuscript. All authors contributed equally.

\section{Funding}

This work has received funding from the European Research Council (ERC) under the European Union's Horizon 2020 research and innovation program (Project GENIORS, Grant No. 755171). This work has benefited from the equipment and framework of the COMP-HUB Initiative, funded by the "Departments of Excellence" program of the Italian Ministry for Education, University and Research (MIUR, 2018-2022)

Notes

The authors declare no competing financial interest.

\section{REFERENCES}

(1) Modolo, G.; Geist, A.; Miguirditchian, M. Minor actinide separations in the reprocessing of spent nuclear fuels: recent advances in Europe. In Reprocessing and Recycling of Spent Nuclear Fuel, Taylor, R., Ed.; Woodhead Publishing: Cambridge, UK, 2015.

(2) Joly, P.; Boo, E. SACSESS roadmap-actinide separation processes; SACSESS, 2015.

(3) OECD-NEA State-of-the-art report on the progress of nuclear fuel cycle chemistry, NEA No. 7267; OECD, Nuclear Energy Agency: Paris, France, 2018.
(4) Weaver, B.; Kappelmann, F. A. TALSPEAK: a new method of separating americium and curium from the lanthanides by extraction from an aqueous solution of an aminopolyacetic acid complex with a monoacidic organophosphate or phosphonate, USAEC report ORNL3559; Oak Ridge National Laboratory: Oak Ridge, TN, 1964.

(5) Nilsson, M.; Nash, K. L. Review article: a review of the development and operational characteristics of the TALSPEAK process. Solvent Extr. Ion Exch. 2007, 25 (6), 665-701.

(6) Geist, A.; Müllich, U.; Magnusson, D.; Kaden, P.; Modolo, G.; Wilden, A.; Zevaco, T. Actinide(III)/Lanthanide(III) Separation Via Selective Aqueous Complexation of Actinides(Iii) Using a Hydrophilic 2,6-Bis(1,2,4-Triazin-3-yl)-Pyridine in Nitric Acid. Solvent Extr. Ion Exch. 2012, 30 (5), 433-444.

(7) Gelis, A. V.; Lumetta, G. J. Actinide lanthanide separation process-ALSEP. Ind. Eng. Chem. Res. 2014, 53 (4), 1624-1631.

(8) Wilden, A.; Modolo, G.; Kaufholz, P.; Sadowski, F.; Lange, S.; Sypula, M.; Magnusson, D.; Müllich, U.; Geist, A.; Bosbach, D. Laboratory-scale counter-current centrifugal contactor demonstration of an innovative-SANEX process using a water soluble BTP. Solvent Extr. Ion Exch. 2015, 33 (2), 91-108.

(9) Wagner, C.; Müllich, U.; Geist, A.; Panak, P. J. Selective Extraction of Am(III) from PUREX Raffinate: The AmSel System. Solvent Extr. Ion Exch. 2016, 34 (2), 103-113.

(10) Heathman, C. R.; Grimes, T. S.; Jansone-Popova, S.; Roy, S.; Bryantsev, V. S.; Zalupski, P. R. Influence of a pre-organized N-donor group on the coordination of trivalent actinides and lanthanides by an aminopolycarboxylate complexant. Chem. - Eur. J. 2019, 25 (10), $2545-2555$.

(11) Hérès, X.; Sorel, C.; Miguirditchian, M.; Camès, B.; Hill, C.; Bisel, I.; Espinoux, D.; Eysseric, C.; Baron, P.; Lorrain, B. Results of recent counter-current tests on $A n(I I I) / L n(I I I)$ separation using TODGA extractant, Proceedings of the GLOBAL 2009 Conference-The Nuclear Fuel Cycle: Sustainable Options \& Industrial Perspectives, Paris, France, Sept 6-11, 2009; pp 1127-1132.

(12) Lewis, F. W.; Harwood, L. M.; Hudson, M. J.; Geist, A.; Kozhevnikov, V. N.; Distler, P.; John, J. Hydrophilic sulfonated bis1,2,4-triazine ligands are highly effective reagents for separating actinides(III) from lanthanides(III) via selective formation of aqueous actinide complexes. Chem. Sci. 2015, 6 (8), 4812-4821.

(13) Kaufholz, P.; Modolo, G.; Wilden, A.; Sadowski, F.; Bosbach, D.; Wagner, C.; Geist, A.; Panak, P. J.; Lewis, F. W.; Harwood, L. M. Solvent Extraction and Fluorescence Spectroscopic Investigation of the Selective Am(III) Complexation with TS-BTPhen. Solvent Extr. Ion Exch. 2016, 34 (2), 126-140.

(14) Macerata, E.; Mossini, E.; Scaravaggi, S.; Mariani, M.; Mele, A.; Panzeri, W.; Boubals, N.; Berthon, L.; Charbonnel, M. C.; Sansone, F.; Arduini, A.; Casnati, A. Hydrophilic Clicked 2,6-Bis-triazolylpyridines Endowed with High Actinide Selectivity and Radiochemical Stability: Toward a Closed Nuclear Fuel Cycle. J. Am. Chem. Soc. 2016, 138 (23), 7232-7235.

(15) Bourg, S.; Geist, A.; Adnet, J.-M.; Rhodes, C.; Hanson, B. GENIORS, a new European project addressing Gen IV integrated oxide fuels recycling strategies, Proceedings of GLOBAL 2017, International Nuclear Fuel Cycle Conference, Seoul, Korea, Sept 24-29, 2017.

(16) Madic, C.; Hudson, M. J. In High-level liquid waste Partitioning by means of completely incinerable extractants, EUR 18038; European Commission: Luxembourg, 1998.

(17) Wagner, C.; Mossini, E.; Macerata, E.; Mariani, M.; Arduini, A.; Casnati, A.; Geist, A.; Panak, P. J. Time-Resolved Laser Fluorescence Spectroscopy Study of the Coordination Chemistry of a Hydrophilic CHON [1,2,3-Triazol-4-yl]pyridine Ligand with $\mathrm{Cm}(\mathrm{III})$ and Eu(III). Inorg. Chem. 2017, 56 (4), 2135-2144.

(18) Mossini, E.; Macerata, E.; Wilden, A.; Kaufholz, P.; Modolo, G.; Iotti, N.; Casnati, A.; Geist, A.; Mariani, M. Optimization and SingleStage Centrifugal Contactor Experiments with the Novel Hydrophilic Complexant PyTri-Diol for the i-SANEX Process. Solvent Extr. Ion Exch. 2018, 36 (4), 373-386. 
(19) Trumm, S.; Wipff, G.; Geist, A.; Panak, P. J.; Fanghänel, T. Optimising BTP ligands by tuning their basicity. Radiochim. Radiochim. Acta 2011, 99, 13-16.

(20) Afsar, A.; Laventine, D. M.; Harwood, L. M.; Hudson, M. J.; Geist, A. Utilizing electronic effects in the modulation of BTPhen ligands with respect to the partitioning of minor actinides from lanthanides. Chem. Commun. 2013, 49 (76), 8534-8536.

(21) Edwards, A. C.; Wagner, C.; Geist, A.; Burton, N. A.; Sharrad, C. A.; Adams, R. W.; Pritchard, R. G.; Panak, P. J.; Whitehead, R. C.; Harwood, L. M. Exploring electronic effects on the partitioning of actinides(III) from lanthanides(III) using functionalised bis-triazinyl phenanthroline ligands. Dalton Trans 2016, 45 (45), 18102-18112.

(22) Antoni, P.; Hed, Y.; Nordberg, A.; Nystrom, D.; von Holst, H.; Hult, A.; Malkoch, M. Bifunctional dendrimers: from robust synthesis and accelerated one-pot postfunctionalization strategy to potential applications. Angew. Chem., Int. Ed. 2009, 48 (12), 2126-30.

(23) Sasaki, Y.; Sugo, Y.; Suzuki, S.; Tachimori, S. The novel extractants, diglycolamides, for the extraction of lanthanides and actinides in $\mathrm{HNO}_{3} / \mathrm{n}$-dodecane system. Solvent Extr. Ion Exch. 2001, 19 (1), 91-103.

(24) Ansari, S. A.; Pathak, P. N.; Manchanda, V. K.; Husain, M.; Prasad, A. K.; Parmar, V. S. N,N, $\mathrm{N}^{\prime}, \mathrm{N}^{\prime}$-tetraoctyl diglycolamide (TODGA): a promising extractant for actinide partitioning from highlevel waste (HLW). Solvent Extr. Ion Exch. 2005, 23 (4), 463-479.

(25) Ansari, S. A.; Pathak, P.; Mohapatra, P. K.; Manchanda, V. K. Chemistry of diglycolamides: promising extractants for actinide partitioning. Chem. Rev. 2012, 112 (3), 1751-1772.

(26) Sasaki, Y.; Tsubata, Y.; Kitatsuji, Y.; Sugo, Y.; Shirasu, N.; Morita, Y.; Kimura, T. Extraction behavior of metal ions by TODGA, DOODA, MIDOA, and NTAamide extractants from $\mathrm{HNO}_{3}$ to ndodecane. Solvent Extr. Ion Exch. 2013, 31 (4), 401-415.

(27) Whittaker, D.; Geist, A.; Modolo, G.; Taylor, R.; Sarsfield, M.; Wilden, A. Applications of diglycolamide based solvent extraction processes in spent nuclear fuel reprocessing, part 1: TODGA. Solvent Extr. Ion Exch. 2018, 36 (3), 223-256.

(28) Piotto, M.; Saudek, V.; Sklenar, V. Gradient-tailored excitation for single-quantum NMR spectroscopy of aqueous solutions. J. Biomol. NMR 1992, 2 (6), 661-665.

(29) Sklenar, V.; Piotto, M.; Leppik, R.; Saudek, V. GradientTailored Water Suppression for $1 \mathrm{H}-15 \mathrm{~N}$ HSQC Experiments Optimized to Retain Full Sensitivity. J. Magn. Reson., Ser. A 1993 , 102 (2), 241-245.

(30) Lee, C.; Yang, W.; Parr, R. G. Development of the ColleSalvetti correlation-energy formula into a functional of the electron density. Phys. Rev. B: Condens. Matter Mater. Phys. 1988, 37 (2), 785789.

(31) Weigend, F.; Ahlrichs, R. Balanced basis sets of split valence, triple zeta valence and quadruple zeta valence quality for $\mathrm{H}$ to $\mathrm{Rn}$ : Design and assessment of accuracy. Phys. Chem. Chem. Phys. 2005, 7 (18), 3297-3305.

(32) TURBOMOLE V7.0, a development of University of Karlsruhe and Forschungszentrum KarlsruheGmbH, 1989-2007; TURBOMOLE $\mathrm{GmbH}$, since 2007. http://www.turbomole.com.

(33) Becke, A. D. A new mixing of Hartree-Fock and local densityfunctional theories. J. Chem. Phys. 1993, 98 (2), 1372-1377.

(34) Kollwitz, M.; Gauss, J. A direct implementation of the GIAOMBPT(2) method for calculating NMR chemical shifts. Application to the naphthalenium and anthracenium ions. Chem. Phys. Lett. 1996, 260 (5-6), 639-646.

(35) Trumm, M.; Schimmelpfennig, B.; Geist, A. Structure and separation quality of various $\mathrm{N}$ - and $\mathrm{O}$-donor ligands from quantumchemical calculations. Nukleonika 2015, 60 (4), 847-851.

(36) Küchle, W.; Dolg, M.; Stoll, H.; Preuss, H. Energy-adjusted pseudopotentials for the actinides. Parameter sets and test calculations for thorium and thorium monoxide. J. Chem. Phys. 1994, 100 (10), $7535-7542$.

(37) Trumm, M.; Schimmelpfennig, B. Towards the origin of effective $\mathrm{An}(\mathrm{III}) / \mathrm{Ln}(\mathrm{III})$ separation by tridentate $\mathrm{N}$-donor ligands: a theoretical study on atomic charges and polarisabilities for $\mathrm{Cm}(\mathrm{III}) /$ Gd(III) separation. Mol. Phys. 2016, 114 (6), 876-883.

(38) Dunning, T. H. Gaussian basis sets for use in correlated molecular calculations. I. The atoms boron through neon and hydrogen. J. Chem. Phys. 1989, 90 (2), 1007-1023.

(39) Hirshfeld, F. L. Bonded-Atom Fragments for Describing Molecular Charge-Densities. Theoretica Chimica Acta 1977, 44 (2), 129-138.

(40) Kimura, T.; Choppin, G. R. Luminescence study on determination of the hydration number of $\mathrm{Cm}(\mathrm{III})$. J. Alloys Compd. 1994, 213, 313-317.

(41) Choppin, G. R. Comparative solution chemistry of the $4 \mathrm{f}$ and $5 \mathrm{f}$ elements. J. Alloys Compd. 1995, 223 (2), 174-179.

(42) Ensor, D. D.; Choppin, G. R. The thermodynamics of complexing of $\mathrm{Ln}(\mathrm{III})$ and $\mathrm{Am}(\mathrm{III})$ by chloroacetates. J. Inorg. Nucl. Chem. 1980, 42 (10), 1477-1480.

(43) Benay, G.; Schurhammer, R.; Desaphy, J.; Wipff, G. Substituent effects on BTP's basicity and complexation properties with $\mathrm{Ln}(\mathrm{III})$ lanthanide ions. New J. Chem. 2011, 35 (1), 184-189.

(44) Hofener, S.; Trumm, M.; Koke, C.; Heuser, J.; Ekstrom, U.; Skerencak-Frech, A.; Schimmelpfennig, B.; Panak, P. J. Computing $\mathrm{UV} /$ vis spectra using a combined molecular dynamics and quantum chemistry approach: bis-triazin-pyridine (BTP) ligands studied in solution. Phys. Chem. Chem. Phys. 2016, 18 (11), 7728-36. 


\section{Activation of the Aromatic Core of 3,3'-(pyridine-2,6-diylbis(1H- 1,2,3-triazole-4,1-diyl))bis(propan-1-ol) - Effects on Extraction Performance, Stability Constants and Basicity}

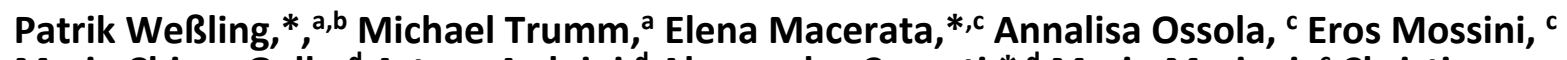
Maria Chiara Gullo, ${ }^{d}$ Arturo Arduini, ${ }^{d}$ Alessandro Casnati, ${ }^{*, d}$ Mario Mariani, ${ }^{c}$ Christian Adam, ${ }^{a}$ Andreas Geist, ${ }^{a}$ and Petra J. Panak ${ }^{a, b}$

a. Karlsruhe Institute of Technology (KIT), Institute for Nuclear Waste Disposal (INE), P.O. Box 3640, 76021 Karlsruhe, Germany

b. Ruprecht-Karls-Universität Heidelberg, Institut für Physikalische Chemie, Im Neuenheimer Feld 253, 69120 Heidelberg, Germany

c. Politecnico di Milano, Department of Energy, Nuclear Engineering Division, Piazza Leonardo da Vinci 32, 20133 Milano, Italy

d. Università di Parma, Dipartimento di Scienze Chimiche, della Vita e della Sostenibilità Ambientale, Area delle Scienze 17/a, 43124 Parma, Italy.

Corresponding Author

Patrik Weßling: $\quad$ patrik.wessling@kit.edu

Alessandro Casnati: alessandro.casnati@unipr.it

Elena Macerata: elena.macerata@polimi.it 
Species distribution for the protonation of PTD-OMe as a function of the measured $\mathrm{pH}$.

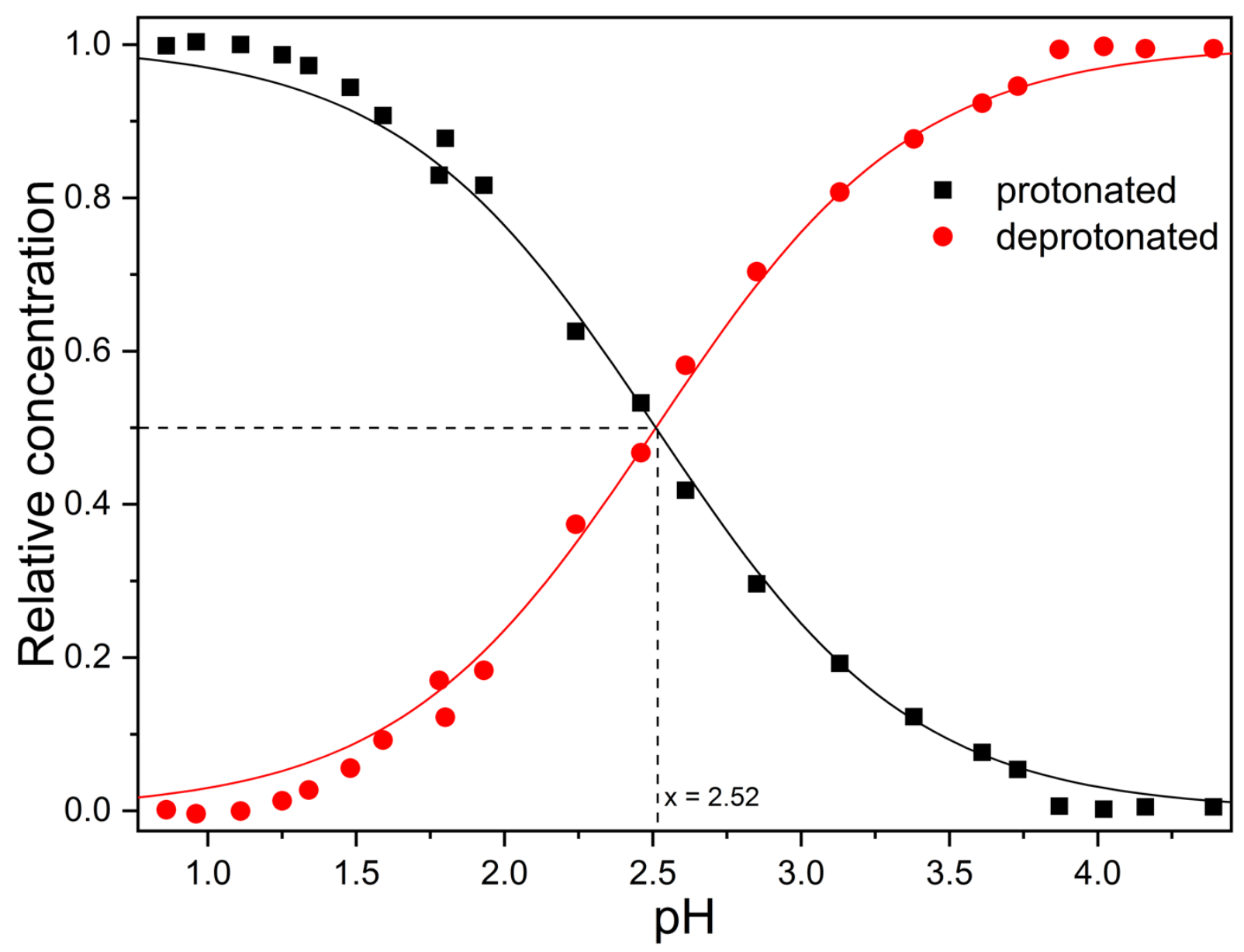

Fig. S 1. Species distribution for the protonation of PTD-OMe as a function of the measured $\mathrm{pH}$. Symbols, experimental data. Lines, calculated with $\mathrm{pK}_{\mathrm{a}}=2.52$. 
Slope analysis for the protonation of PTD-OMe.

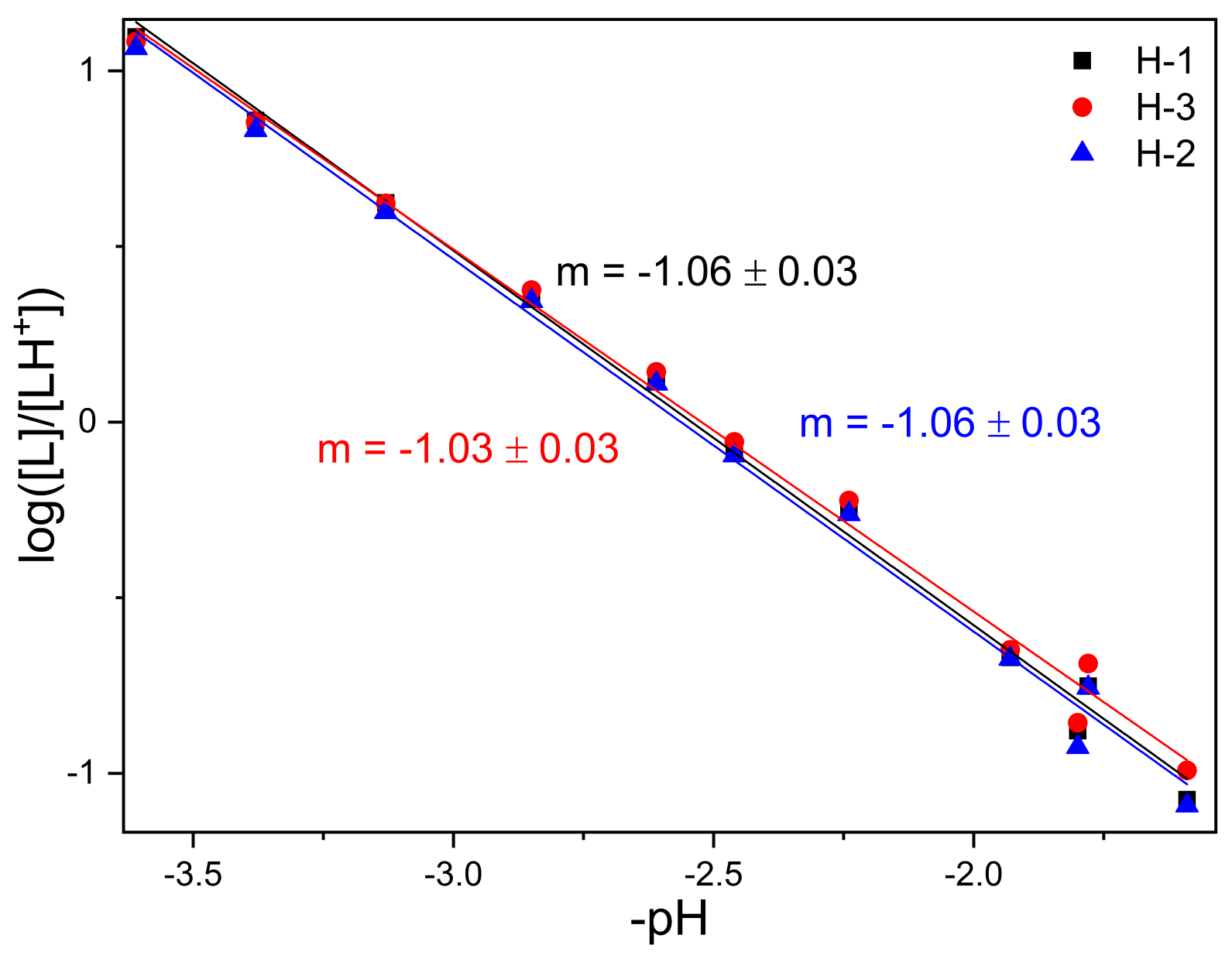

Fig. S 2. Double logarithmic plot of $\log \left([\mathrm{L}] /\left[\mathrm{LH}^{+}\right]\right)$versus the negative measured $\mathrm{pH}$. 
Fluorescence lifetime of $\left[\mathrm{Cm}(\mathrm{PTD}-\mathrm{OMe})_{3}\right]^{3+}$ in $10^{-3} \mathrm{~mol} / \mathrm{L} \mathrm{HClO}$.

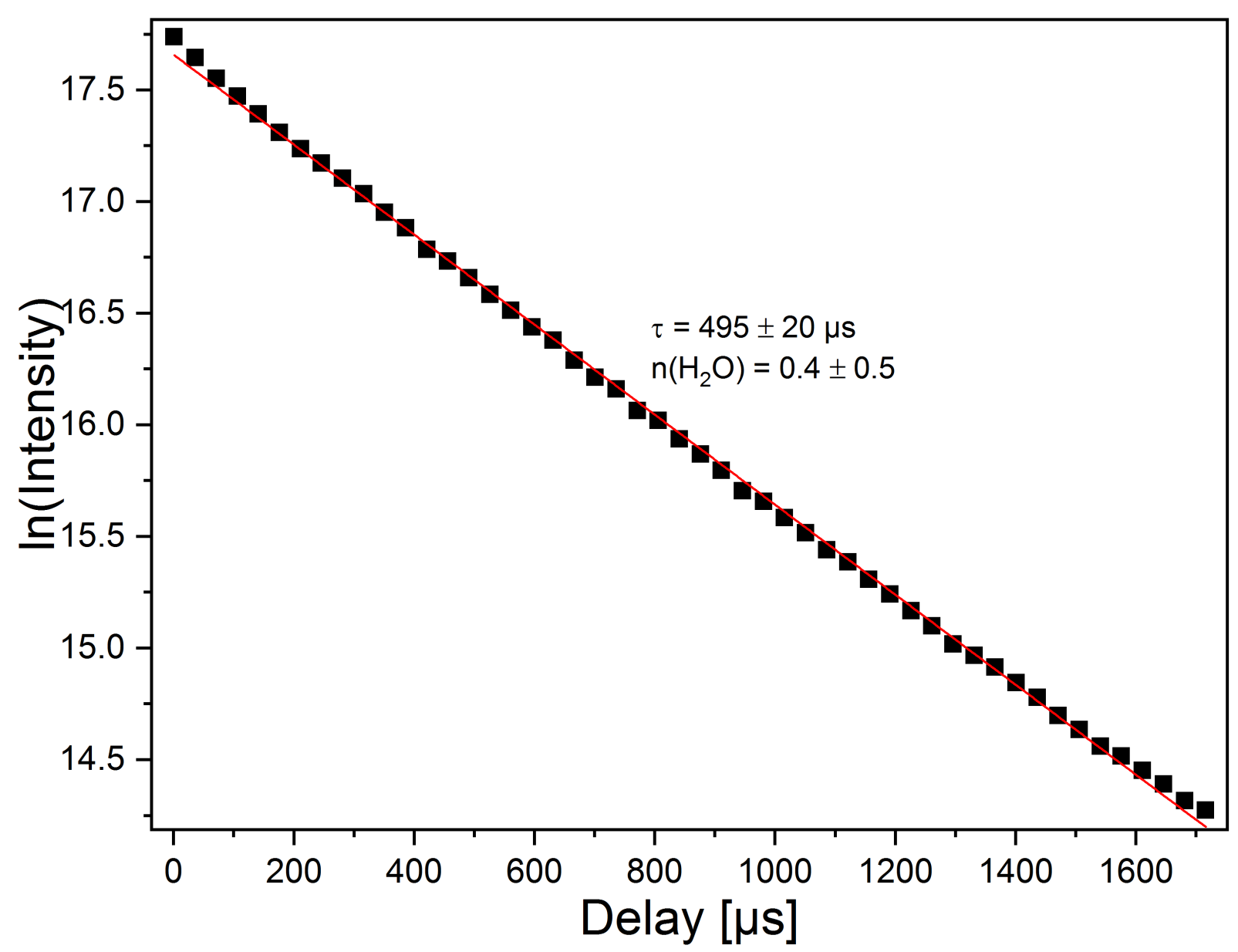

Fig. S 3. Decrease of the fluorescence intensity of $\mathrm{Cm}(\mathrm{III})$ in $10^{-3} \mathrm{~mol} / \mathrm{L} \mathrm{HClO}_{4} ; \mathrm{C}(\mathrm{PTD}-\mathrm{OMe})=$ $6.29 \times 10^{-3} \mathrm{~mol} / \mathrm{L}, \mathrm{c}(\mathrm{Cm})=1 \times 10^{-7} \mathrm{~mol} / \mathrm{L}$. 
Slope analysis for the complexation of $\mathrm{Cm}(\mathrm{III})$ with PTD-OMe in $10^{-3} \mathrm{~mol} / \mathrm{L} \mathrm{HClO} 4$.

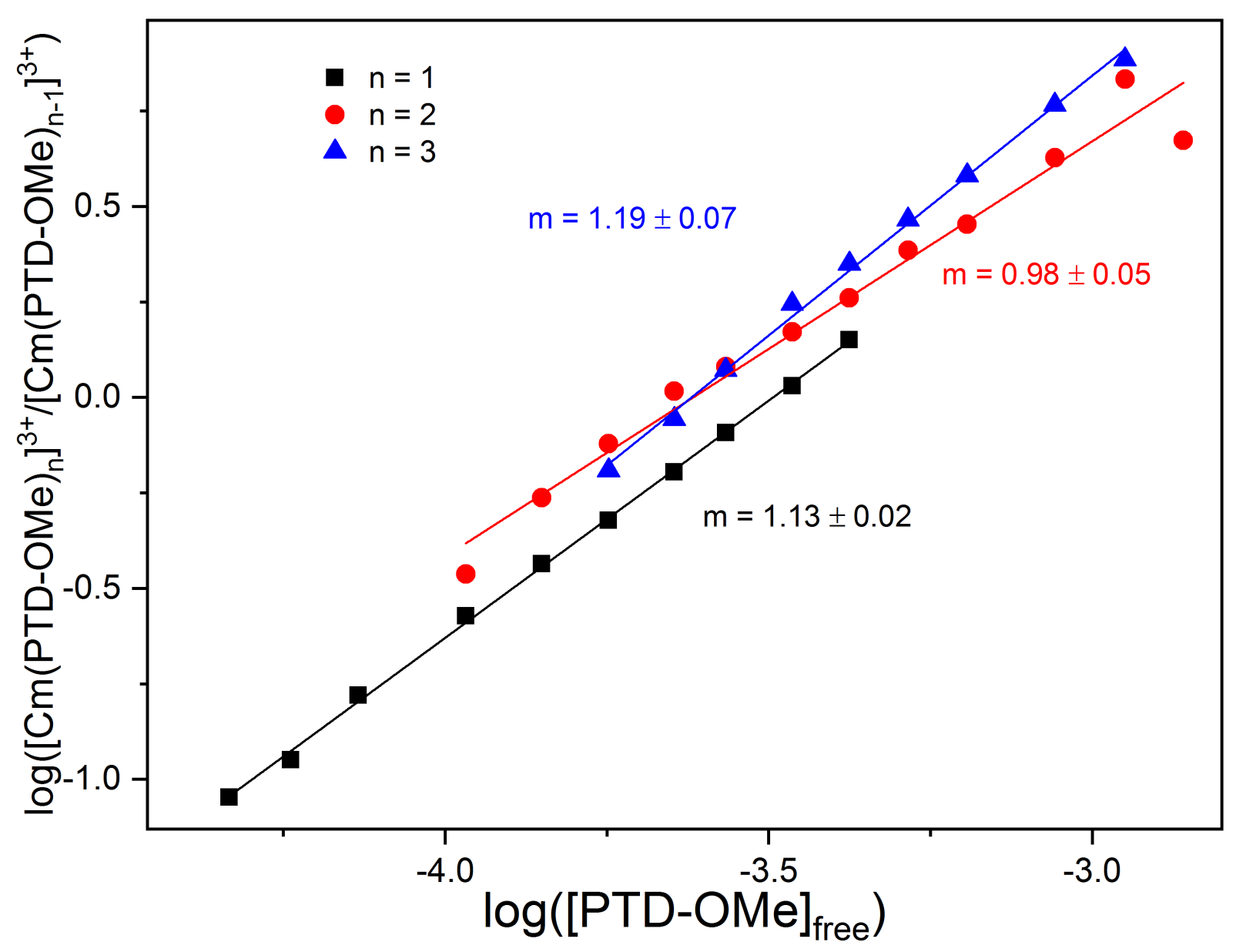

Fig. S 4. Double logarithmic plot of $\log \left(\left[\mathrm{Cm}(\mathrm{PTD}-\mathrm{OMe})_{n}\right]^{3+} /\left[\mathrm{Cm}(\mathrm{PTD}-\mathrm{OMe})_{n-1}\right]^{3+}\right)$ versus the free PTD-OMe concentration. 
Fluorescence lifetime measurement of $\mathrm{Cm}$ (III) of a solvent extraction experiment with TODGA/PTD-OMe

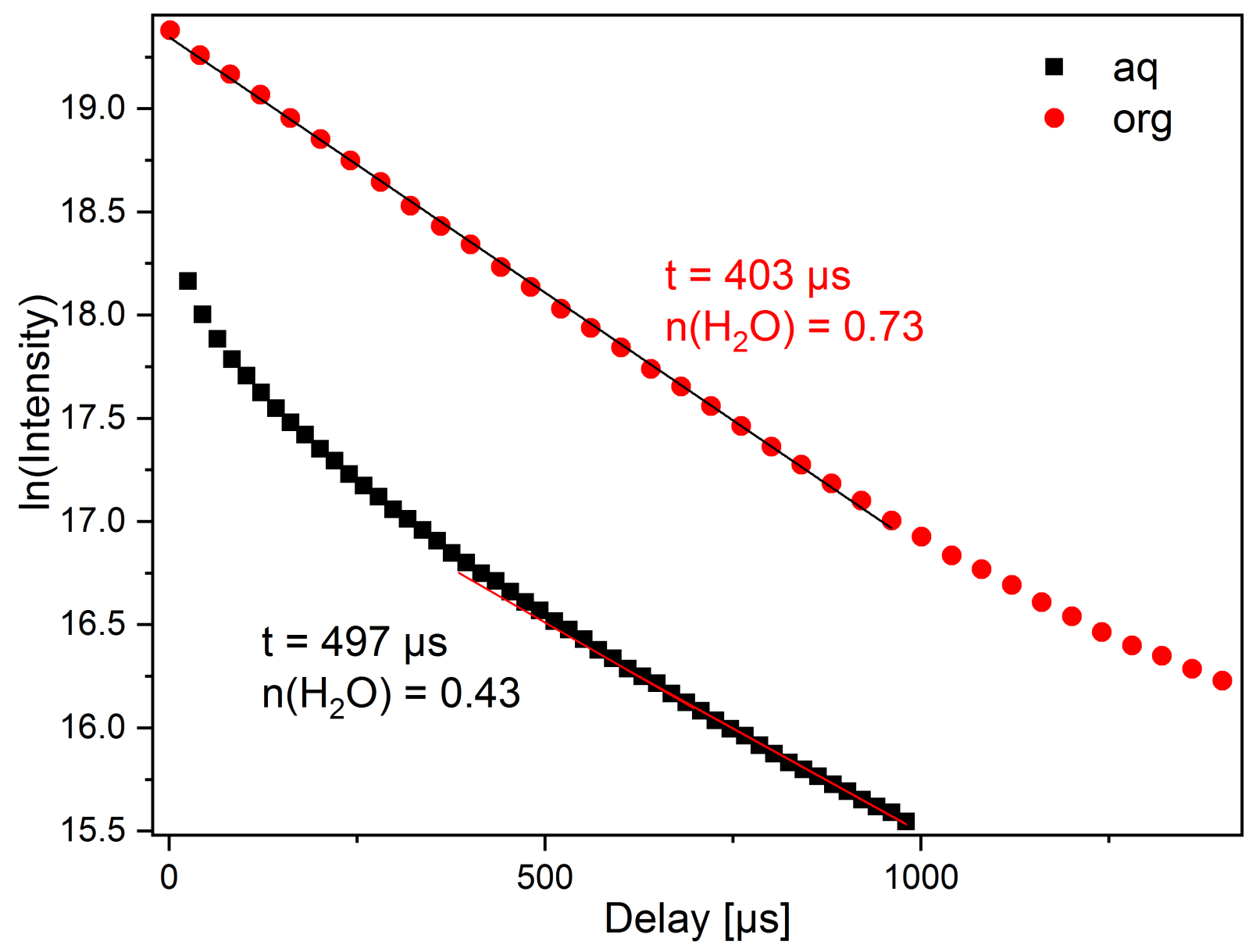

Fig. S 5. Decrease of the fluorescence intensity of $\mathrm{Cm}(\mathrm{III})$ in the organic and aqueous phases of a solvent extraction sample. $0.08 \mathrm{~mol} / \mathrm{L}$ PTD-OMe in $0.44 \mathrm{~mol}^{-} \mathrm{L} \mathrm{HNO}_{3} ; 0.2 \mathrm{~mol} / \mathrm{L} \mathrm{TODGA}$ in TPH + 5 vol.\% 1-octanol; $\left.\mathrm{c}(\mathrm{Cm})_{\text {ini }}=1 \times 10^{-7} \mathrm{~mol} / \mathrm{L}\right)$.

Calculated distances between $\mathrm{M}(\mathrm{III})$ and coordinating nitrogen atoms

Tab. $S 1$ Calculated distances between the metal ions and the coordinating nitrogen atoms in A of the optimized $\left[\mathrm{M}(\mathrm{PTD})_{3}\right]^{3+}$ and $\left[\mathrm{M}(\mathrm{PTD}-\mathrm{OMe})_{3}\right]^{3+}(\mathrm{M}=\mathrm{Cm}, \mathrm{Gd})$

\begin{tabular}{|c|c|c|c|c|}
\hline & \multicolumn{2}{|c|}{ PTD } & \multicolumn{2}{c|}{ PTD-OMe } \\
\hline $\mathrm{M}(\mathrm{III})$ & $\mathrm{N}^{1}$ & $\mathrm{~N}^{2}$ & $\mathrm{~N}^{1}$ & $\mathrm{~N}^{2}$ \\
\hline $\mathrm{Cm}$ & 2.681 & 2.591 & 2.664 & 2.593 \\
\hline $\mathrm{Gd}$ & 2.643 & 2.550 & 2.627 & 2.555 \\
\hline
\end{tabular}

